\title{
Unexpected inflation, capital structure and real risk-adjusted firm performance
}

\author{
Jamie Alcock ${ }^{\mathrm{A}}$ and Eva Steiner ${ }^{*}$,B

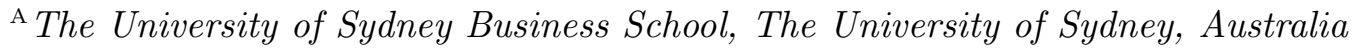 \\ ${ }^{\mathrm{B}}$ Department of Land Economy, University of Cambridge, United Kingdom.
}

\begin{abstract}
Managers can improve real risk-adjusted firm performance by matching nominal assets with nominal liabilities, thereby reducing the sensitivity of real risk-adjusted returns to unexpected inflation. The Net Asset Value (NAV) of US equity Real Estate Investment Trusts (REITs) serves as a good proxy for nominal assets and accordingly we use a sample of US REITs to test our hypothesis. We find that for the firms in our sample: (i) their real, risk-adjusted performance, and (ii) their inflation hedging qualities are inversely related to deviations from this "matchingnominals" argument. In addition to providing managers with a vehicle to maximise real, risk-adjusted performance, our findings also provide investors with the tools to infer inflation-hedging qualities of equity investments.
\end{abstract}

\section{- WORK IN PROGRESS - \\ DO NOT CITE OR QUOTE WITHOUT PERMISSION}

Key words: REITs, leverage, inflation hedging, real risk-adjusted performance JEL: G00, G31, R30

\footnotetext{
* Corresponding Author: Department of Land Economy, University of Cambridge, 19 Silver Street, Cambridge CB3 9EP, UK, es434@cam.ac.uk. We thank Dirk Brounen, John Duca, Martin Hoesli, Andrew Karolyi, David Ling, Colin Lizieri, Seow Eng Ong, Raghavendra Rau, the participants of the Joint AREUEA International \& AsRES Meeting 2012 and the 4th RECAPNET Conference, as well as the seminar participants at the University of Cambridge and the University of Exeter for their helpful comments and suggestions. The usual disclaimer applies.
} 


\section{Introduction}

One of the fundamental motivations for investing in financial assets is arguably to accumulate wealth in order to fund future consumption (Merton, 1969). The ability to consume out of wealth is determined by its real purchasing power. However, the purchasing power of wealth depends on the price level and is thus a real, rather than a nominal concept (Ritter, 2002). From this point of view, firm managers should aim to maximise real, rather than nominal, risk-adjusted performance. Managers can arguably influence real risk-adjusted firm performance through a variety of means, especially the pursuit of a suitable investment policy that determines the firm's asset structure. In this study, we argue that, conditional on a given asset structure, a firm can optimise its real risk-adjusted performance through the choice of an appropriate financing policy. We propose that real risk-adjusted returns to equity are a function of the firm's holdings of nominal and real assets and liabilities and that managers can optimise real, risk-adjusted returns by matching the holdings of nominal liabilities with nominal assets.

Real risk-adjusted performance is difficult to optimise partly due to the variation in the general price level. In an efficient market, the returns on nominal contracts account for expected inflation (Bach and Stephenson, 1974; Fama, 1970). However, the uncertainty surrounding unexpected inflation is more difficult to manage. Figure 1 shows that expected US CPI inflation averaged 0.2\% per month between 1989 and 2011. However, over the same time period, the volatility of monthly unexpected inflation also averaged $0.2 \%$. These statistics suggest that under a Normal distribution, there is a c. $15 \%$ chance that inflation was more than twice as high, in a given month, as expected. Furthermore, unexpected inflation has increased over the last 22 years, peaking at $0.6 \%$ per month in 2008 . This observation suggests that the risk of unexpected inflation is of growing importance, especially given the uncertain longer-term consequences of recent expansionary monetary policy measures.

The net balance of nominal assets and liabilities influences the real return to equity, as well as its volatility, by modifying the exposure of equity to expected and unexpected inflation risks. Real risk-adjusted performance, ceteris paribus, is conditionally maximised when nominal liabilities are matched with nominal assets in an increasing, monotonic fashion. The appropriate choice of nominal liabilities for a given level of nominal assets reduces the volatility of the real return to equity by 
attenuating the impact of unexpected inflation, thereby improving the risk efficiency of an investment in the firm's equity.

Previous authors have found it difficult to identify and measure nominal and real assets and liabilities (Amihud, 1996; French, Ruback, and Schwert, 1983). We study a sample of US Real Estate Investment Trusts (REITs) to test the "matchingnominals" hypothesis. REITs represent a useful case study because they follow a regulated business model of investing in and deriving income from operating real estate assets, which simplifies the composition of their balance sheet. We employ the net asset value (NAV) of the REITs as our proxy for nominal assets. Detailed data on REIT NAVs is available from a REIT-specific data provider. Our empirical evidence suggests that the NAV is insensitive to inflation, confirming that it represents a suitable proxy for nominal assets. In sum, our focus on REITs enables us to distinguish effectively between real and nominal assets and liabilities, reducing potential measurement errors and increasing the power of our empirical tests.

Our argument produces two main testable implications. First, if our rationale is correct, then we expect firms that match nominal assets with nominal liabilities to deliver stronger real risk-adjusted performance, ceteris paribus. Further, we also expect these firms to offer stronger inflation hedging qualities to their equity investors, ceteris paribus. Consequently, we explore empirically whether real risk-adjusted firm performance and the strength of a firm's inflation hedging qualities decline in the deviation from the match between nominal assets and liabilities that we propose. We find that departures from this match significantly reduce real risk-adjusted performance as measured by the real Sharpe ratio, and also significantly impair inflation hedging qualities.

Our findings have several implications for managers and investors. We offer a simple rule that allows managers to improve real risk-adjusted performance and hedge unexpected inflation. Further, our results imply that investors can infer inflation hedging capabilities of equity investments from the firm's capital structure. In addition, our findings suggest that firms may hold leverage in excess of firm-characteristic informed target levels in order to manage the exposure of equity to unexpected inflation risks and improve real risk-adjusted performance. Our results also contribute to the debate about the inflation-hedging qualities of equities investments. We suggest that variation in these qualities may be a function of capital structure.

We proceed as follows: Section 2 presents the model alongside a set of simulation re- 
sults to derive testable implications. Section 3 presents data, method and descriptive statistics, Section 4 discusses our empirical results, and Section 5 concludes.

\section{Real risk-adjusted returns and capital structure}

The Modigliani-Miller irrelevance proposition (Modigliani and Miller, 1963) states that nominal risk-adjusted returns cannot be improved through capital structure, as investors can employ home-made leverage to replicate the financing strategy of the firm. However, Frazzini and Pedersen (2011) argue that there are leverageconstrained investors, such as pension funds, who are unable to employ home-made leverage. Consistent with this view, we argue that these leverage-constrained investors benefit from delegating the management of capital structure choices to the firm. On the other hand, unconstrained investors are still in a position to leverage and de-leverage in order to manage capital structure, performance and inflation hedging objectives independently at no extra cost. On balance, a firm is able to increase the supply of its capital by expanding the potential investor base to include leverage-constrained investors. In this context, a manager acting in the interests of shareholders is concerned with the real, risk-adjusted return to equity.

Consider a simple, mature firm that holds a combination of assets and liabilities. These contracts can be classified as either nominal or real. Contracts whose value fluctuates with the prevailing price level are classified as real contracts and contracts whose value is uncorrelated with the prevailing price level are classified as nominal contracts. The asset structure of the firm is determined exogenously via its investment policy. Once the asset holding has been determined, the manager's objective is then to identify an appropriate liability structure that will maximise the real, risk-adjusted returns to equity.

If we consider a simple one-period, deterministic framework and let $E_{0}$ denote the mareket price of firm equity at time $t=0$, defined as the sum ofthe market value of real and nominal assets and liabilities:

$$
E_{0}=\left(M V A_{0}^{R}-M V L_{0}^{R}\right)+\left(M V A_{0}^{N}-M V L_{0}^{N}\right)
$$

where $M V A_{0}^{R}$ and $M V L_{0}^{R}$ are the market values of the firm's real assets and liabilities at time $t=0$, and where $M V A_{0}^{N}$ and $M V L_{0}^{N}$ are the corresponding market values of the nominal assets and liabilities. We assume $E_{0}>0$. At $t=1$, unexpected 
inflation has caused the general price level to change at rate $e^{u}$ so that the value of firm equity at $t=1, E_{1}$, is then:

$$
E_{1}=\left(M V A_{0}^{R} e^{\kappa}-M V L_{0}^{R}\right) e^{r+u}+\left(M V A_{0}^{N} e^{\kappa}-M V L_{0}^{N}\right) e^{r+\alpha}
$$

where $r$ is the premium for real corporate debt $L_{0}^{R}$ over the risk-free rate measured at time $t=1$. The variables $\kappa$ and $\alpha$ represent the the premia that differentiates the return on assets from that on liabilities, and returns on nominal assets and liabilities from those on their real counterparts, respectively. [TO Do, fix this] The total, one-period, continuously compounded excess return on firm equity, $R$, is then given by:

$$
R=\ln \left[\frac{E_{1}}{E_{0}}\right]=\ln \left[\frac{\left(M V A_{0}^{R} e^{\kappa}-M V L_{0}^{R}\right) e^{r+u}+\left(M V A_{0}^{N} e^{\kappa}-M V L_{0}^{N}\right) e^{r+\alpha}}{\left(M V A_{0}^{R}-M V L_{0}^{R}\right)+\left(M V A_{0}^{N}-M V L_{0}^{N}\right)}\right]
$$

Accounting for inflation, the one-period real excess return on firm equity, $R^{R}$, is:

$$
R^{R}=\ln \left[\frac{\left(M V A_{0}^{R} e^{\kappa}-M V L_{0}^{R}\right) e^{r}+\left(M V A_{0}^{N} e^{\kappa}-M V L_{0}^{N}\right) e^{r+\alpha-u}}{\left(M V A_{0}^{R}-M V L_{0}^{R}\right)+\left(M V A_{0}^{N}-M V L_{0}^{N}\right)}\right]
$$

The sensitivity of real equity returns to unexpected inflation, $S$, is given by the partial derivative of $R^{R}$ with respect to $u$ :

$$
S=\frac{\partial R^{R}}{\partial u}=\frac{-e^{-u}\left(M V A_{0}^{N} e^{r+\alpha+\kappa}-M V L_{0}^{N} e^{r+\alpha}\right)}{E_{1}}
$$

Setting $S$ to zero and solving for the level of nominal liabilities yields:

$$
S=0 \Longrightarrow M V L_{0}^{N}=M V A_{0}^{N} e^{\kappa} \Longrightarrow M V L_{0}^{N} \propto M V A_{0}^{N}
$$

That is, the sensitivity to unexpected inflation of real returns to equity is minimised by setting nominal liabilities to be in direct proportion to the nominal assets of the firm. If the net nominal position (assets minus liabilities) is zero, then the firms remaining real position will move in line with the general price level and so will generate real returns.

To maximise real, risk-adjusted returns to equity we optimise the trade-off between risk and return in the mean-variance framework, that is by maximising the real Sharpe ratio (Sharpe, 1966, 1994), defined as the ratio of the expectation and the 
standard deviation of $R^{R}$ :

$$
S R^{R}=\frac{E\left[R^{R}\right]}{S D\left[R^{R}\right]}
$$

We employ a set of simple simulations to illustrate the evolution of the components of $S R^{R}$ as a function of nominal assets and liabilities in a stochastic setting. We allow each of the variables, $\alpha, u, \kappa$ and $r$ to be normally distributed such that: ${ }^{2}$

$$
\left[\begin{array}{lll}
\alpha & u \kappa r
\end{array}\right]^{T} \sim N\left(\left[\begin{array}{llll}
0.05 & 0 & 0.05 & 0.05
\end{array}\right]^{T}, \operatorname{DIAG}\left(\left[\begin{array}{llll}
0.05 & 0.05 & 0.04 & 0.1
\end{array}\right]\right)\right),
$$

where DIAG $(a b c d)$ is the $4 \times 4$ matrix with $(a b c d)$ along the diagonals and zeros elsewhere.

For each combination of nominal assets and liabilities along a range of possible values, we calculate $E\left[R^{R}\right]$ and $S D\left[R^{R}\right]$ over the distribution of $r, u, \alpha$ and $\kappa$. Figure 2(a) shows the results for $E\left[R^{R}\right]$. This expectation increases in nominal assets because nominal assets contribute positively to the return on equity by earning the premium for expected inflation, $\alpha$. For a given level of nominal assets, $E\left[R^{R}\right]$ is a linear, decreasing function of nominal liabilities. Increasing nominal liabilities for a given level of nominal assets reduces the net nominal position $\left(M V A_{0}^{N}-M V L_{0}^{N}\right)$, and thus the exposure of equity to the return benefits of $\alpha$. As equity is the residual of assets and liabilities, a unit-change in nominal liabilities results in a constant rate of change in $E\left[R^{R}\right]$, irrespective of the current level of nominal assets. This represented by the constant negative slope of the relationship between $E\left[R^{R}\right]$ and nominal liabilities in Figure 2(a).

Figure 2(b) shows the results for $S D\left[R^{R}\right]$. For positive shifts in the level of nominal assets, $S D\left[R^{R}\right]$ generally increases. The reverse occurs at very high levels of nominal liabilities. Then $S D\left[R^{R}\right]$ decreases in the level of nominal assets. The non-linear evolution of $S D\left[R^{R}\right]$ reflects the interactions between nominal assets and liabilities in determining the exposure of equity to unexpected inflation risks.

The sensitivity of the real return on equity to unexpected inflation risk depends upon the net nominal position of the firm. When nominal liabilities are low, then increasing nominal assets increases the net nominal position and thus the sensitivity of the real return on equity to unexpected inflation. As a result, $S D\left[R^{R}\right]$ increases.

2 We choose parameter values to easily identify a general trend. Simulation results using different values generate qualitatively similar results. 
When nominal assets and liabilities are approximately equal so that the net nominal position of the firm is balanced, then this sensitivity is minimised. However, as the level of nominal liabilities increases further, the net nominal position drifts out of balance again. Consequently, the exposure of equity to unexpected inflation risks increases, and so does the standard deviation of the real return to equity. When nominal liabilities are high, an increase in nominal assets helps rebalance the net nominal position, reduces the exposure to unexpected inflation risks and thus results in a lower $S D\left[R^{R}\right]$.

The ratio of these values gives the real Sharpe ratio as a function of nominal assets and liabilities (Figure 3). The real Sharpe ratio is the product of the overall trade-off between the costs and benefits of nominal assets and liabilities, namely, the exposure to the return benefits of $\alpha$ and the exposure to unexpected inflation risks.

Higher levels of nominal assets increase the maximum $S R^{R}$ achievable, simply because the return-enhancing effect of nominal assets as these assets capture the return benefits of $\alpha$. For a given level of nominal assets, $S R^{R}$ is a concave function of nominal liabilities reflecting the non-linear relationship between $S D\left[R^{R}\right]$ and the net nominal position. When nominal liabilities are low, for a given level of nominal assets, an additional unit of nominal liabilities reduces $S D\left[R^{R}\right]$ by more than it detracts from $E\left[R^{R}\right]$. On balance then, this additional unit of nominal liabilities increases the real Sharpe ratio. For low levels of nominal liabilities, the marginal effect of a reduction in the return sensitivity to unexpected inflation from an additional unit of nominal liabilities outweighs that of the reduction in the expected return on equity from foregoing some of the return benefits of $\alpha$.

Balancing the risk and return drivers then, can result in a level of nominal liabilities that maximises $S R^{R}$. Beyond the maximum $S R^{R}$, an additional unit of nominal liabilities reduces $S D\left[R^{R}\right]$ by less than it detracts from $E\left[R^{R}\right]$. The negative effect of nominal liabilities on the numerator of $S R^{R}$ from foregoing the benefits of $\alpha$ outweighs the positive effect on the denominator from lower sensitivity to unexpected inflation. Recall that this volatility-reducing effect is reversed when nominal liabilities become large (Figure 2(b)). This reversal is also reflected in the increasing downward slope of $S R^{R}$ as a function of nominal liabilities. On balance, beyond the optimum of $S R^{R}$, an additional unit of nominal liabilities decreases $S R^{R}$.

The optimal level of nominal liabilities that maximises $S R^{R}$ occurs where the differentials of $E\left[R^{R}\right]$ and $S D\left[R^{R}\right]$ are equal. At this point, the marginal volatility- 
reducing effect of an additional unit of nominal liabilities is equal to the marginal return-reducing impact from this additional unit. However, the figure suggests that the Sharpe ratio-maximising amount of nominal liabilities is lower than the amount that minimises $S D\left[R^{R}\right]$. This difference is due to the fact that, on average, a unitincrease in nominal liabilities reduces $S D\left[R^{R}\right]$ by less than it reduces $E\left[R^{R}\right]$. This occurs because beyond the minimum of $S D\left[R^{R}\right]$, an additional unit of nominal liabilities increases $S D\left[R^{R}\right]$ again. Therefore, the ratio between $E\left[R^{R}\right]$ and $S D\left[R^{R}\right]$ is maximised before $S D\left[R^{R}\right]$ is minimised.

The optimal, real Sharpe-ratio maximising amount of nominal liabilities is a positive linear function of nominal assets. For $S D\left[R^{R}\right]$, the optimal trade-off between the costs and benefits of nominal assets and liabilities is achieved by linearly matching these items, as with the deterministic case (6). For the real Sharpe ratio, which is a direct function of $S D\left[R^{R}\right]$, this optimal trade-off is still achieved by maintaining a linear matching relationship between nominal assets and liabilities. However, the constant of proportionality appears to be smaller because, on average, a unit increase in nominal liabilities reduces $S D\left[R^{R}\right]$ by less than it reduces $E\left[R^{R}\right]$. This differential impact shifts the optimal amount of nominal liabilities to the left.

Figure 4 summarises the optimal linear relationship between nominal assets and liabilities that maximises $S R^{R}$, given our simulation parameters. In both the deterministic and stochastic cases, the real, risk-adjusted return to equity is maximised by setting the amount of nominal liabilities to be a monotonically increasing, linear function of nominal assets.

Our central claim then, is that matching nominal assets and liabilities improves real risk-adjusted returns. Accordingly, we expect that deviations from the optimal match between nominal assets and liabilities are inversely related to the firm's real Sharpe ratio. Central to this claim is that any improvement in real risk-adjusted performance is related with a stronger hedge against unexpected inflation. In other words, we suggest that deviations from the optimal match between nominal assets and liabilities are inversely related to unexpected inflation hedging qualities of an investment into the firm's equity. Specifically, we test the following hypotheses.

Hypothesis 1: A firm's real Sharpe ratio is inversely related to the deviation from the optimal match between nominal assets and liabilities.

Hypothesis 2: A firm's unexpected inflation hedging qualities are inversely related 
to the deviation from the optimal match between nominal assets and liabilities.

\section{Data and method}

Several authors have noted difficulty with identifying a good proxy for nominal assets (Amihud, 1996; French, Ruback, and Schwert, 1983). We employ the Net Asset Value (NAV) of US equity Real Estate Investment Trusts (REITs) as a proxy for nominal assets. Equity REITs mainly derive income from leasing real estate assets (Lehman and Roth, 2010). Rental payments under existing leases may be fixed for considerable periods of time, if not the duration of the lease. Leases may reflect inflation through indexation clauses that periodically adjust the rent to the currently prevailing price level. However, given the discrete and infrequent nature of these reviews, rental payments are relatively insensitive to changes in the price level. Therefore, property leases are often considered a nominal asset (Hoesli, Lizieri, and MacGregor, 2008; Zarowin, 1988).

The NAV reflects the book value of these leases as it is calculated by discounting the expected rental income derived from these leases at an appropriate rate and deducting any debt employed in the acquisition of the underlying properties (Chan, Erickson, and Wang, 2003). Consistent with the characteristics of nominal contracts in efficient markets (Bach and Stephenson, 1974; Fama, 1970), the rental income projected on the basis of the leases will likely reflect expected inflation. However, these projections cannot account for unexpected inflation. Therefore, in line with the definition of nominal assets, the REIT's NAV does not reflect unexpected inflation. Figures 5 and 6 show that the natural logarithm of NAV is unrelated to unexpected inflation (measured as the residuals after filtering monthly logged CPI figures using an $\operatorname{ARIMA}(0,1,1)$ specification (Fama and Gibbons, 1984; Vassalou, 2000)).

We use this insight to establish the suitability of Net Asset Value as a proxy for Nominal Assets. Recall that NAV is the difference between Gross Assets and Total Debt, or in terms of nominal assets and debt:

$$
\mathrm{NAV}=A^{R}+A^{N}-L^{R}-L^{N} .
$$

As NAV is insensitive to inflation, it follows that the real components have a negligible net impact on NAV. Hence we suggest that a good proxy for nominal assets is 
the sum of NAV and nominal debt. That is,

$$
\hat{A}^{N}=\mathrm{NAV}+L^{N}
$$

The optimal "matching-nominals" relationship is then captured by:

$$
\begin{aligned}
L^{N} & =\beta \hat{A}^{N}+\epsilon \\
& =\Theta \mathrm{NAV}+\epsilon, \quad \text { where } \Theta=\frac{\beta}{1-\beta}
\end{aligned}
$$

So the deviations from this relationship are then given by

$$
L^{N}-\beta \hat{A}^{N}=\left(L^{N}-\hat{\Theta} \mathrm{NAV}\right)
$$

with $\hat{\Theta}$ given by the coefficient of the regression of nominal debt against NAV. While $\mathrm{NAV}$ is an imperfect proxy for nominal assets, the bias in using this proxy ( $\beta=$ $\Theta /(\Theta+1))$ filters through so as to not obfuscate the inferences made using $\left(L^{N}-\right.$ $\Theta N A V)$ as the proxy for deviations from the "matching-nominals" relationship.

The suitability of our proxy is dependent upon the insentivity of NAV to unexpected inflation. Table 1 presents the results from a set of fixed-effects panel regressions of the natural logarithm of the firm's NAV as reported by $S N L$ (discounted at an average rate of $7.5 \%$ ) on unexpected inflation (Column (1)) and the lag of unexpected inflation (Column (2)). Columns (3) and (4) replicate these regressions in first differences. Based on these regression results, we accept that NAV is insensitive to unexpected inflation and so accept that our proxy for deviation (from the matching-nominals relationship) is sound. To proxy for nominal liabilities, we employ the firm's holdings of fixed-rate debt, following Flannery and James (1984). $S N L$ provides detailed panel data on REIT NAV and fixed-rate debt.

We test our hypotheses using all listed US REITs (SIC code 6798), with the exception of mortgage REITs (GIC Code 40402030), in the cross-section of $S N L$ and Compustat from the inception of $S N L$ in 1989 to 2011. All balance sheet data is from $S N L$ and Compustat. Firm returns are from the Center for Research in Security Prices $(C R S P)$. Inflation data is from the Bureau of Labor Statistics. Bond yields are from the Federal Reserve. Data on the market, size and value factors as well as the risk-free rate are from Kenneth French's database.

We discard observations where the ratio of long-term debt to total debt, nominal 
assets to all assets or nominal liabilities to all liabilities lies outside the interval $[0,1]$. All continuous variables are winsorised at the $1^{\text {st }}$ and $99^{\text {th }}$ percentiles. We measure earnings volatility and abnormal earnings contemporaneously to the observation of the dependent variable. We measure all other variables at the fiscal year-end prior to that (Billett, King, and Mauer, 2007; Johnson, 2003).

\subsection{Empirical method}

Liability matching and real risk-adjusted performance

First, we explore the relationship between real risk-adjusted performance and the optimal match between nominal assets and liabilities. We relate a firm-year panel of the annual real Sharpe ratios $\left(S R^{R}\right)$ of the REITs to a proxy for their annual deviations from this optimal match $(D E V)$. We obtain the annual real Sharpe ratios of the sample firms on the basis of monthly $C R S P$ return data.

We argue that the Sharpe ratio-maximising amount of nominal liabilities is proportional to nominal assets. The optimal constant of proportionality may differ for each firm in each year, depending on the actual prevailing values of the parameters in our model. For the empirical implementation, we examine a number of alternatives for the parameter characterising the relationship between nominal assets and liabilities. We assume direct proportionality as the optimal relationship between nominal assets and liabilities. We measure the deviation from the optimal match between nominal assets and liabilities for each firm-year, $D E V$, by computing the annual squared differences between actual nominal liabilities and assets. ${ }^{3}$

We estimate the following fixed-effects panel model:

$$
\begin{aligned}
S R_{i t}^{R} & =\beta_{0}+\beta_{1} D E V_{i t}+\beta_{2} L N S I Z E_{i t}+\beta_{3} P R O F I T_{i t}+\beta_{4} M B_{i t}+\beta_{5} F A R_{i t} \\
& +\beta_{6} A B E A R N_{i t}+\beta_{7} V O L_{i t}+\beta_{8} D N O L_{i t}+\beta_{9} M A T_{i t}+u_{i t}
\end{aligned}
$$

where $u_{i t}$ is the residual and standard errors are clustered by firm (Petersen, 2009; Thompson, 2011). Real risk-adjusted performance may be viewed as a function of the firm's investment decisions and, as we suggest, its financing policy. We include dummies for the firm's property sector as a proxy for the firm's investment strategy. The property sector of a REIT arguably determines the type of leases, including

3 For robustness, we parametrise the optimal proportional relationship between nominal assets and liabilities using empirical coefficient values obtained from a set of regressions of actual nominal liabilities on actual nominal assets. We then measure the deviation as the annual squared differences between actual nominal liabilities and the amounts of nominal assets derived from the empirical parametrisation. The results are robust to these different parametrisations. 
indexation clauses. Therefore, the property sector may have an immediate impact on real risk-adjusted performance. We also control for the set of capital structure controls from Table 2. We account for latent economic shock factors using year dummies. Consistent with Hypothesis 1 , we expect a negative sign on $\beta_{1}$ in (8).

In order to explore the relative sensitivity of changes in the real Sharpe ratio to changes in the deviation from the optimal match between nominal assets and liabilities, we re-estimate equation (8) in first differences.

\section{Liability matching and inflation hedging qualities}

In order to examine the relationship between the unexpected inflation hedging qualities of an investment into the firm's equity and the optimal match between nominal assets and liabilities, we relate the annual sensitivity of monthly nominal firm returns to unexpected inflation to the deviation variable, $D E V$. In the calculation of $D E V$, we assume direct proportionality between nominal assets and liabilities.

A stock is considered an inflation hedge if an inflationary shock does not affect real returns, or, equivalently, if an inflationary shock results in a positive change in nominal returns (Alchian and Kessel, 1959; Bodie, 1976; Branch, 1974; Fama and MacBeth, 1974; Lintner, 1973; Oudet, 1973). It is not possible to provide statistical evidence for the absence of a relationship between real returns and inflation. Therefore, we examine the relationship between nominal returns and inflation. We estimate each firm's unexpected inflation hedging qualities using annual regressions of the nominal monthly excess firm returns (NRET) on monthly unexpected inflation (UINFL) and a set of controls. We compile a firm-year panel of the annual coefficients measuring the sensitivity of nominal firm returns to unexpected inflation. A higher positive coefficient value suggests stronger unexpected inflation hedging qualities.

We measure unexpected inflation as the residual from filtering monthly logged CPI figures using an $\operatorname{ARIMA}(0,1,1)$ specification (Fama and Gibbons, 1984; Vassalou, 2000), and expected inflation as the predicted values from this exercise. ${ }^{4}$

In this regression, we control for the excess return on the market $(M K T)$, size $(S M L)$ and value $(H M L)$ factors, expected inflation $(E X P I N)$ and variation in

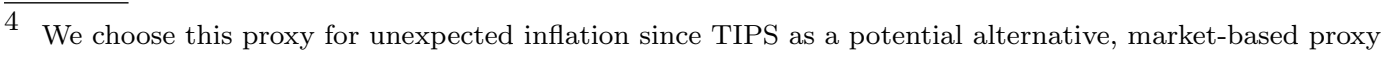
are only available for maturities in excess of five years. 
the interest rate proxied by changes in the federal funds rate $(C F F R)$ :

$$
\begin{aligned}
\text { REET }_{i t} & =\gamma_{0}+\gamma_{1} U I N F L_{t}+\gamma_{2} M K T_{t}+\gamma_{3} S M B_{t}+\gamma_{4} H M L_{t} \\
& +\gamma_{5} E X P I N_{t}+\gamma_{6} C F F R_{t}+e_{i t}
\end{aligned}
$$

where $e_{i t}$ is the residual. We collect the $\gamma_{1}$ coefficients to compile a firm-year panel of unexpected inflation sensitivities UINFLS. We then regress these UINFLS on our proxy for the deviations from the optimal match between nominal assets and liabilities $(D E V)$. We control for the usual set of capital structure determinants, including maturity, as well as property type and year dummies. We estimate the following fixed-effects panel model:

$$
\begin{aligned}
U I N F L S_{i t} & =\beta_{0}+\beta_{1} D E V_{i t}+\beta_{2} L N S I Z E_{i t}+\beta_{3} P R O F I T_{i t}+\beta_{4} M B_{i t} \\
& +\beta_{5} A B E A R N_{i t}+\beta_{6} V O L_{i t}+\beta_{7} D N O L_{i t}+\beta_{8} M A T_{i t}+u_{i t}
\end{aligned}
$$

where $u_{i t}$ is the residual. We remedy the bias in the standard errors from heteroskedasticity potentially introduced by the estimated dependent variable in (10) using heteroskedasticity-robust standard errors clustered by firm (Lewis and Linzer, 2005; Petersen, 2009; Thompson, 2011). Consistent with Hypothesis 3, we expect a negative sign on $\beta_{1}$ in (10).

In order to explore the relative sensitivity of changes in the firm's inflation hedging characteristics to changes in the deviation from the optimal match between nominal assets and liabilities, we re-estimate this specification in first differences.

\subsection{Descriptive statistics}

Table 3 presents the descriptive statistics for the period 1989-2011. The mean nominal debt (assets) to equity ratio is 1.91 (2.41). The mean firm size is US $\$ 1.28 \mathrm{bn}$ (in constant August 1982 US\$, deflated using PPI). The mean debt maturity, measured as the ratio of long-term debt to total debt, is $49 \%$. Asset maturity averages 33 years, supporting the notion that the useful life of real estate assets is relatively long. The profitability of the sample firms averages $8 \%$. The mean market-to-book ratio is 1.24. This value is broadly consistent with Alcock, Steiner, and Tan (2014). This observation suggests that the stable REIT business model of owning and operating real estate assets offers low growth opportunities.

The volatility of earnings is relatively low at $2 \%$. This observation supports the no- 
tion that REITs focus on a stable business model as suggested in (Boudry, Kallberg, and Liu, 2010). Approximately $9 \%$ of all firm-year observations have losses carried forward. Almost $48 \%$ of firm-year observations have debt ratings present.

Table 4 presents the pairwise Pearson correlation coefficients between the main predictors. Correlations are generally low with the exception of the log of nominal assets and firm size. This observation validates our range of alternative measures that we employ in order to control for the effect of firm size in the analysis of Hypothesis 1.

Figure 7 shows a histogram with descriptive statistics for the unexpected inflation sensitivity coefficients we estimate. The mean inflation sensitivity of the nominal returns of our sample firms is significantly positive. This observation suggests that on average for our study period, US listed equity REITs offer some inflation hedging qualities. However, the histogram shows considerable dispersion around the mean. Some firm-year observations have significantly positive values of unexpected inflation sensitivity, while others have significantly negative values. This range of values implies substantial variation in inflation hedging qualities. Our empirical results, discussed below, suggest that this variation may be related to capital structure choices.

\section{Results}

Table 5 presents the regression results for Hypothesis 1 over the study period 1989 to 2011. ${ }^{5}$ Our results support the predicted relationship between the firm's liability structure and its real risk-adjusted performance. We find an inverse linear relationship between the deviation from the optimal match between nominal assets and liabilities and the real Sharpe ratio, after controlling for a set of variables reflecting that real risk-adjusted performance is the product of the firm's investment decisions and its financing choices. Our evidence is robust to different parameter choices for the constant of proportionality characterising the optimal matching relationship between nominal assets and liabilities (Columns 1 to 3). Our result is consistent with our model's implication that capital structure choices and real risk-adjusted performance are related. Our finding suggests that, everything else being equal, a firm that adheres to the optimal matching relationship between nominal assets and liabilities

\footnotetext{
5 In unreported results, we find that our evidence is robust to excluding the period prior to 1992, marking the introduction of the UPREIT legislation and thus the beginning of the modern REIT era, sometimes considered a structural break in the REIT history. Our evidence is also robust to excluding the period after 2007, marking the onset of the recent global financial crisis.
} 
achieves a higher real Sharpe ratio. ${ }^{6}$

However, our result also suggests that the relationship between the real Sharpe ratio and deviations from the optimal match between nominal assets and liabilities is not strictly linear. Column 4 of Table 5 presents the effect of changes in the deviation from the optimal amount of nominal liabilities on changes in the real Sharpe ratio. ${ }^{7}$ The corresponding coefficient is significantly negative. Larger deviations from the optimum appear to have a decreasing relative negative impact on the real Sharpe ratio. The marginal effect of an additional small shift away from the optimal amount of nominal liabilities appears to be decreasing. As a result, managers have a strong incentive to make small adjustments towards the optimal balance of nominal assets and liabilities when the current deviation is small. As this deviation becomes larger, the incentive to make more significant adjustments appears to become stronger.

Hypothesis 2 refers to the relationship between the firm's liability structure and its characteristics as a hedge against unexpected inflation. Table 6, Column 1, presents the regression results of the firms' annual unexpected inflation betas on the deviation from the optimal match between nominal assets and liabilities. ${ }^{8}$ Our results hold when controlling, amongst others, for the property sector of the REITs that we employ as a proxy for the investment strategy of the firm. This sector arguably determines the structure of the leases and thus the terms under which rents adjust to inflation. Our finding suggests that the liability structure of the firm has a significant impact on unexpected inflation hedging qualities that is separate from the influence of the asset and lease structures determined by the investment strategy of the firm.

More specifically, we find that deviations from the optimal match between nominal assets and liabilities reduce the firm's unexpected inflation beta. In our empirical setting, a higher inflation beta stands for a higher sensitivity of the firm's nominal return to unexpected inflation. Therefore, a higher beta implies a superior hedge against unexpected inflation. Our results suggest that observing the linear relationship between nominal assets and liabilities modifies the sensitivity of the nominal

\footnotetext{
6 For robustness, we also explore the possibility of asymmetric consequences on real risk-adjusted performance of firms holding either excess or insufficient amounts of nominal liabilities. We augment the relevant regressions by an indicator for the sign of the raw deviation before squaring the difference in the construction of $D E V$. We find no evidence for such asymmetries, suggesting that any deviations from the optimal amount of nominal liabilities reduce real risk-adjusted performance, irrespective of their sign.

7 Given the robustness of our results to the different parameter choices for the constant to proportionality, we focus here on the directly proportional case.

8 Given the robustness of our results up to this point to the different choices for the constant of proportionality characterising the linear matching relationship between nominal assets and liabilities, from now on, we focus our discussion on the results for the directly proportional case.
} 
return on equity to unexpected inflationary shocks. Consequently, it appears that matching nominal assets and liabilities reduces the adverse effects of unexpected inflation. In combination, our findings suggest a conceptual link between capital structure choices, inflation hedging qualities and real risk-adjusted firm performance.

Further, we find that the firm's unexpected inflation hedging qualities are inversely related to debt maturity. This finding suggests that, everything else being equal, an increase in the holdings of long-term debt appears to attenuate the inflation sensitivity of the firm's nominal returns. Our results also suggest that the firm's unexpected inflation hedging qualities are negatively related to the market-to-book ratio. The market-to-book ratio reflects the extent to which the market value of the firm is backed by assets in place. A higher market-to-book ratio suggests that the firm has growth opportunities that have not materialised into nominal or real assets in place yet. The inflation hedging qualities we explore relate to the extent to which nominal assets in place are financed with nominal debt. A higher market-tobook ratio, suggesting fewer assets in place relative to the market value of the firm, appears to leave equity more exposed to unexpected inflation and, as a result, to attenuate the inflation hedging qualities of investments into the firm's equity.

Column 2 of Table 6 presents the effect of a change in the deviation from the optimal match between nominal assets and liabilities on the change in the firms unexpected inflation beta. The sign on the coefficient is negative, resonating the result for changes in real risk-adjusted performance, but here the coefficient is not statistically significant. Our evidence suggests that the marginal effect on inflation hedging qualities of an additional small shift away from the optimal match between nominal assets and liabilities is constant. Our result implies that the incentives for firm managers to correct deviations from the optimal match in order to improve the unexpected inflation hedging qualities of investments into their firm's equity do not appear to vary by the magnitude of the current deviation.

Our findings imply that inflation hedging qualities of REITs may vary across firms as a function of their capital structure. Several studies find evidence against the suitability of listed REITs as an inflation hedge, consistent with results commonly established for industrial stocks. ${ }^{9}$ Darrat and Glascock (1989) consider the role of

\footnotetext{
9 See, for instance, Brueggeman, Chen, and Thibodeau (1984); Chan, Hendershott, and Sanders (1990); Chatrath and Liang (1998); Ewing and Payne (2005); Goebel and Kim (1989); Gyourko and Linneman (1988); Park, Mullineaux, and Chew (1990); Titman and Warga (1986); Yobaccio, Rubens, and Ketcham (1995).
} 
monetary policy, real economic and financial indicators. Subsequently, Glascock, Lu, and So (2002) argue that monetary policy drives the spurious negative relationship between REIT returns and inflation. Simpson, Ramchander, and Webb (2007) distinguish between positive and negative changes in expected and unexpected inflation and present evidence consistent with the suitability of equity REITs as an inflation hedge. Hardin, Jiang, and Wu (2012) argue that inflation illusion may drive the observation that in the short-term, REIT returns often appear to be negatively related to expected inflation. However, many studies to date focus on the index level and thus implicitly assume that inflation hedging properties are equal across firms or exogenously determined. Our findings provide a fundamental economic rationale behind potential variation in inflation hedging properties across REITs that is related to the capital structure choices of these firms.

Further, Case and Wachter (2011) postulate that if firms are net debtors, they will benefit from unexpected changes in the price level through the redistribution effects of inflation. They argue that REITs holding relatively large amounts of fixed-rate debt should on average have relatively stronger returns, all else equal, during periods of high inflation. However, these authors stop short of exploring the empirical evidence for their argument. We present empirical evidence in favour of their argument.

More generally, our findings explore the relationship between the balance of a firm's nominal assets and liabilities and the sensitivity of its equity returns to unexpected inflation. First, firms may not on average be net (nominal) debtors but, as our evidence suggests, match nominal liabilities to nominal assets. The resulting crosssectional variation in nominal liabilities that is difficult to incorporate into analyses on the index level may be partly responsible for the lack of strong evidence for REITs as an inflation hedge. Further, firms may not universally benefit from simply holding more nominal debt. Instead, the exact choice of the amount and term of nominal debt that has to be matched with the amount and maturity of nominal assets appears to matter. This explains why on average, a relationship between total nominal liabilities and the inflation sensitivity of REIT returns may seem weak.

Furthermore, our results imply that REITs hold nominal debt to match nominal assets. Our findings thus contribute to the debate about the potential drivers of REIT leverage choices. This debate is driven by the difficulty to reconcile the theoretical lack of incentive for REITs to use debt with the empirical observation that these firms tend to hold significant levels of leverage, and often more than unregulated 
firms in a comparable line of business (Alcock, Steiner, and Tan, 2014; Harrison, Panasian, and Seiler, 2011). ${ }^{10}$ Against this background, several authors suggest potential alternative explanations for the determinants of REIT leverage choices. Brown and Riddiough (2003) report that REITs appear to target leverage in order to maintain an investment-grade debt rating. Ooi, Ong, and Li (2010) and Boudry, Kallberg, and Liu (2010) suggest that REIT debt issuance decisions are consistent with the market timing theory (Baker and Wurgler, 2002). Further, Feng, Ghosh, and Sirmans (2007) suggest that REITs trade off the lack of incentive for debt and the adverse selection cost of equity. Alcock, Steiner, and Tan (2014) find that REITs use debt to signal firm quality and optimise transaction costs. Alcock, Glascock, and Steiner (2013) suggest that REITs employ leverage to manage market exposure and modify risk-adjusted performance. In spite of these numerous suggestions for the drivers of REIT capital structure decisions, Harrison, Panasian, and Seiler (2011) conclude that a closer investigation and better understanding of the leverage choices of these firms is needed. Our results suggest that REITs hold debt to match nominal assets in an effort to improve real risk-adjusted performance by managing unexpected inflationary shocks.

\section{Conclusion}

In this study, we model the real risk-adjusted return on firm equity as a function of nominal as well as real assets and liabilities. We show that, everything else being equal, firms can choose a capital structure to improve real risk-adjusted performance by matching nominal assets with nominal liabilities in a monotonically increasing, linear fashion. We illustrate that in doing so, firms reduce the sensitivity of real riskadjusted returns to unexpected inflation, improving the risk efficiency of investments into their equity. Overall, our study establishes a simple interrelationship between capital structure, real risk-adjusted performance and the inflation hedging qualities of equities investments.

In order to test the resulting hypotheses, we focus on a sample of US listed eq-

\footnotetext{
$\overline{10}$ The interest in REIT capital structure decisions is particularly fuelled by the limited explanatory power of traditional leverage theories given the tax exemption of REITs, their strict pay-out requirements and straight-forward business model. Howe and Shilling (1988) assert that in the absence of tax benefits, REITs cannot compete for debt and will favour equity. Shilling (1994) argues that REIT value is maximised for equity-only financing. Boudry, Kallberg, and Liu (2010) argue that, given their simple business model of owning and operating real estate, REITs are a fairly transparent investment vehicle, limiting asymmetric information problems and thus the relevance of the traditional pecking order theory. Pecking order also assumes discretion over earnings, debt and equity. However, REIT pay-out requirements (Lehman and Roth, 2010) largely restrict funding choices to debt and equity.
} 
uity REITs, facilitating the identification of the relevant variables, thus reducing measurement errors and improving the statistical power of our empirical tests. Consistent with our hypotheses, we find that US listed equity REITs that adhere to the suggested match between nominal assets and liabilities outperform their peers in terms of the real Sharpe ratio. We further find that increasing deviations from the optimal match between nominal assets and liabilities reduce the unexpected inflation hedging qualities of investments into the firms' equity.

Our findings have a number of practical implications. Financial managers are able to employ our findings in the development of strategies to enhance real risk-adjusted performance, conditional on a given asset structure. For investors, our finding suggests that they are able to utilise information on the firm's liability structure to draw inferences about the firm's potential to deliver strong real risk-adjusted performance. Our results therefore have the potential to assist investors in improving the basis of their decision-making process and help promote more efficient investment decisions.

In a wider context, our study contributes to the debate about the drivers of corporate leverage choices. We provide evidence consistent with the hypothesis that firms choose debt holdings so as to improve real risk-adjusted performance via the modification of equity exposure to unexpected inflationary shocks. Our results also contribute to the debate about inflation hedging characteristics of equities investments. We provide evidence that equities investments offer stronger inflation hedging qualities if the firms follow the optimal matching relationship between nominal assets and liabilities. Our results allow us to explore an additional dimension of this debate relating to the potential firm-level variation in inflation hedging characteristics. From this perspective, our findings illustrate how inflation hedging characteristics relate to capital structure choices via the management of the match between nominal assets and liabilities. 


\section{References}

Alchian, A. A., And R. A. Kessel (1959): "Redistribution of wealth through inflation," Science, 130(3375), 535-539.

Alcock, J., J. Glascock, And E. Steiner (2013): "Manipulation in U.S. REIT Investment Performance Evaluation: Empirical Evidence," Journal of Real Estate Finance and Economics, 47(3), 434-465.

Alcock, J., E. Steiner, And K. J. K. TAn (2014): "Joint Leverage and Maturity Choices in Real Estate Firms: The Role of the REIT Status," Journal of Real Estate Finance and Economics, 48(1), 57-78.

Aminud, Y. A. (1996): "Unexpected Inflation and Stock Returns RevisitedEvidence from Israel," Journal of Money, Credit and Banking, 28(1), 22-33.

Bach, G. L., And J. B. Stephenson (1974): "Inflation and the redistribution of wealth," Review of Economics and Statistics, 56(1), 1-13.

BAKer, M., AND J. Wurgler (2002): "Market timing and capital structure," Journal of Finance, 57(1), 1-30.

Billett, M. T., T.-H. D. King, and D. C. Mauer (2007): "Growth opportunities and the choice of leverage, debt maturity, and covenants," Journal of Finance, $62(2), 697-730$.

Bodie, Z. (1976): "Common stocks as a hedge against inflation," Journal of Finance, 31(2), 459-470.

Boudry, W. I., J. G. Kallberg, and C. H. Liu (2010): "An Analysis of REIT Security Issuance Decisions," Real Estate Economics, 38(1), 91-120.

Bradley, M., G. Jarrell, And E. Kim (1984): "On the existence of an optimal capital structure: theory and evidence," Journal of Finance, 39(3), 857-878.

BRANCH, B. (1974): "Common stock performance and inflation: an international comparison," Journal of Business, 47(1), 48-52.

BRICK, I. E., AND S. A. RAVID (1985): "On the relevance of debt maturity structure," Journal of Finance, 40(5), 1423-1437.

Brown, D. T., and T. J. Riddiough (2003): "Financing Choice and Liability Structure of Real Estate Investment Trusts," Real Estate Economics, 31(3), 313346.

Brueggeman, W. B., A. H. Chen, and T. G. Thibodeau (1984): "Real Estate Investment Funds: Performance and Portfolio Considerations," Real Estate Economics, 12(3), 333-354.

CAse, B., AND S. WAChter (2011): "Inflation and Real Estate Investments," Working Paper 11-33, University of Pennsylvania Law School, Institute for Law and Economics.

Chan, K. C., P. H. Hendershott, and A. B. Sanders (1990): "Risk and return on real estate: Evidence from equity REITs," AREUEA Journal, 18(4), 431-452.

Chan, S. H., J. Erickson, And K. WAng (2003): Real Estate Investment Trusts: Structure, Performance and Investment Opportunities. Oxford University Press.

Chatrath, A., And Y. Liang (1998): "REITs and Inflation: A Long-Run Perspective," Journal of Real Estate Research, 16(3), 311-326.

Darrat, A. F., and J. L. Glascock (1989): "Real Estate Returns, Money and Fiscal Deficits: Is the Real Estate Market Efficient?," Journal of Real Estate Finance and Economics, 2(3), 197-208.

DeAngelo, H., And R. Masulis (1980): "Optimal capital structure under corporate and personal taxation," Journal of Financial Economics, 8(1), 3-29.

Diamond, D. W. (1991): "Debt Maturity Structure and Liquidity Risk," Quarterly 
Journal of Economics, 106(3), 709-737.

Donaldson, G. (1961): Corporate debt capacity: a study of corporate debt policy. Harvard Graduate School of Business.

Ewing, B. T., AND J. E. PAYne (2005): "The response of real estate investment trust returns to macroeconomic shocks," Journal of Business Research, 58(3), 293-300.

FAMA, E. F. (1970): "Efficient capital markets: A review of theory and empirical work," Journal of Finance, 25(2), 383-417.

Fama, E. F., And M. R. GibBons (1984): "A comparison of inflation forecasts," Journal of Monetary Economics, 13(3), 327-348.

FAMA, E. F., AND J. D. MACBETh (1974): "Tests of the multiperiod two-parameter model," Journal of Financial Economics, 1(1), 43-66.

Feng, Z., C. Ghosh, and C. Sirmans (2007): "On the Capital Structure of Real Estate Investment Trusts (REITs)," Journal of Real Estate Finance and Economics, 34(1), 81-105.

Flannery, M. J., And C. M. James (1984): "The effect of interest rate changes on the common stock returns of financial institutions," Journal of Finance, 39(4), $1141-1153$.

Frazzini, A., And L. H. Pedersen (2011): "Betting Against Beta," Swiss Finance Institute Research Paper No. 12-1\%.

French, K. R., R. S. Ruback, And G. W. Schwert (1983): "Effects of nominal contracting on stock returns," Journal of Political Economy, 91(1), 70-96.

Glascock, J. L., C. Lu, AND R. W. So (2002): "REIT Returns and Inflation: Perverse or Reverse Causality Effects?," Journal of Real Estate Finance and Economics, 24(3), 301-317.

Goebel, P. H., And K. S. Kim (1989): "Performance Evaluation of Finite-Life Real Estate Investment Trusts," Journal of Real Estate Research, 4(2), 57-70.

Gyourko, J., AND P. Linneman (1988): "Owner-occupied homes, incomeproducing properties, and REITs as inflation hedges: Empirical findings," Journal of Real Estate Finance and Economics, 1(4), 347-372.

Hardin, W. G., X. JiAng, AND Z. Wu (2012): "REIT Stock Prices with Inflation Hedging and Illusion," Journal of Real Estate Finance and Economics, 45(1), $262-287$.

Harrison, D. M., C. A. Panasian, and M. J. Seiler (2011): "Further Evidence on the Capital Structure of REITs," Real Estate Economics, 39(1), 133-166.

Hoesli, M., C. Lizieri, and B. MacGregor (2008): "The Inflation Hedging Characteristics of US and UK Investments: A Multi-Factor Error Correction Approach," Journal of Real Estate Finance and Economics, 36(2), 183-206.

Howe, J. S., AND J. D. Shilling (1988): "Capital Structure Theory and REIT Security Offerings," Journal of Finance, 43(4), 983-993.

Johnson, S. A. (2003): "Debt maturity and the effects of growth opportunities and liquidity risk on leverage," Review of Financial Studies, 16(1), 209-236.

Lehman, R., And H. Roth (2010): "Global Real Estate Investment Trust Report 2010 - Against all odds," Research report, Ernst \& Young.

LEland, H., AND K. TOFT (1996): "Optimal capital structure, endogenous bankruptcy, and the term structure of credit spreads," Journal of Finance, 51(3), 987-1019.

Lewis, J. B., And D. A. Linzer (2005): "Estimating Regression Models in Which the Dependent Variable Is Based on Estimates," Political Analysis, 13(4), 345364 . 
Lintner, J. (1973): "Inflation and common stock prices in a cyclical context," 53rd annual report, National Bureau of Economic Research.

Merton, R. C. (1969): "Lifetime Portfolio Selection under Uncertainty: The Continuous-Time Case," Review of Economics and Statistics, 51(3), 247-257.

Modigliani, F., AND M. Miller (1963): "Corporate income taxes and the cost of capital: a correction," American Economic Review, 53(3), 433-443.

Myers, S. (1977): "Determinants of corporate borrowings," Journal of Financial Economics, 5(2), 147-275.

Myers, S., AND N. MAJLuF (1984): "Corporate financing and investment decisions when firms have information that investors do not have," Journal of Financial Economics, 13(2), 187-221.

OoI, J. T., S.-E. Ong, AND L. Li (2010): "An Analysis of the Financing Decisions of REITs: The Role of Market Timing and Target Leverage," Journal of Real Estate Finance and Economics, 40(2), 130-160.

OUdET, B. A. (1973): "The variation in the return on stocks in periods of inflation," Journal of Financial and Quantitative Analysis, 8(2), 247-258.

Park, J. Y., D. J. Mullineaux, And I.-K. Chew (1990): "Are REITs inflation hedges?," Journal of Real Estate Finance and Economics, 3(1), 91-103.

Petersen, M. (2009): "Estimating standard errors in finance panel data sets: comparing approaches," Review of Financial Studies, 22(1), 435-480.

Ritter, J. R. (2002): "The Biggest Mistakes We Teach," Journal of Financial Research, 25(2), 159-168.

Ross, S. A. (1977): "The determination of financial structure: the incentivesignalling approach," Bell Journal of Economics, 8(1), 23-40.

Sharpe, S. (1991): "Credit rationing, concessionary lending and debt maturity structure," Journal of Banking and Finance, 15(3), 581-604.

Sharpe, W. F. (1966): "Mutual Fund Performance," Journal of Business, 39(1), 119-138.

(1994): "The Sharpe Ratio," Journal of Portfolio Management, 21(1), 4958.

Shilling, J. D. (1994): "Taxes and the Capital Structure of Partnerships, REITs, and Other Related Entities," Working Paper 94-16, Wisconsin-Madison CULER.

Simpson, M. W., S. Ramchander, and J. R. Webb (2007): "The Asymmetric Response of Equity REIT Returns to Inflation," Journal of Real Estate Finance and Economics, 34(4), 513-529.

Thompson, S. B. (2011): "Simple formulas for standard errors that cluster by both firm and time," Journal of Financial Economics, 99(1), 1-10.

Titman, S. (1992): "Interest Rate Swaps and Corporate Financing Choices," Journal of Finance, 47(4), 1503-1516.

Titman, S., AND A. WARga (1986): "Risk and the Performance of Real Estate Investment Trusts: A Multiple Index Approach," Real Estate Economics, 14(3), 414-431.

VASSALOU, M. (2000): "Exchange rate and foreign inflation risk premiums in global equity returns," Journal of International Money and Finance, 19(3), 433-470.

Yobaccio, E., J. H. Rubens, and D. C. Ketcham (1995): "The InflationHedging Properties of Risk Assets: The Case of REITs," Journal of Real Estate Research, 10(3), 279-296.

Zarowin, P. (1988): "Non-linearities and nominal contracting effects: The case of the depreciation tax shield," Journal of Accounting and Economics, 10(2), 89-110. 


\section{$6 \quad$ Figures and tables}

Time series evolution of CPI components 1989-2011

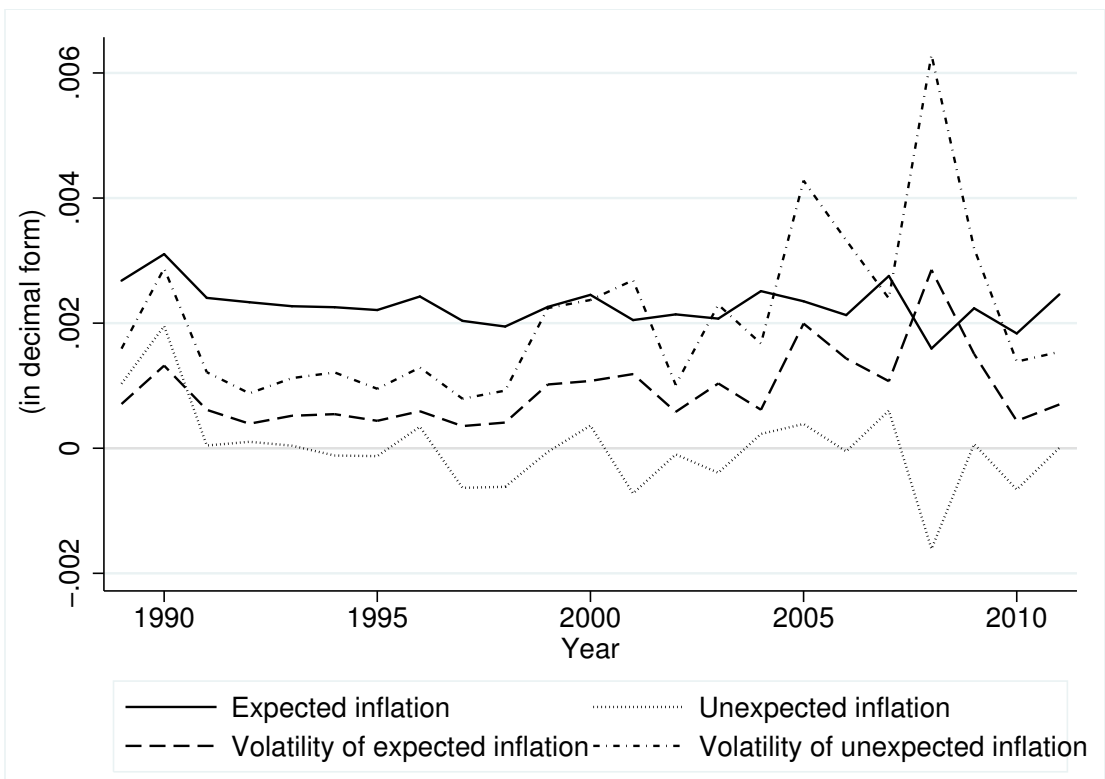

Fig. 1. The figure shows the time series evolution of different aspected of US CPI inflation over the study period. We measure unexpected inflation as the residual from filtering monthly logged CPI figures using an $\operatorname{ARIMA}(0,1,1)$ specification (Fama and Gibbons, 1984; Vassalou, 2000), and expected inflation as the predicted values from this exercise. We measure unexpected (expected) inflation uncertainty as the annual standard deviation of monthly unexpected (expected) inflation figures over 12 months to year-end. 
Simulation for the real excess return to firm equity and its standard deviation

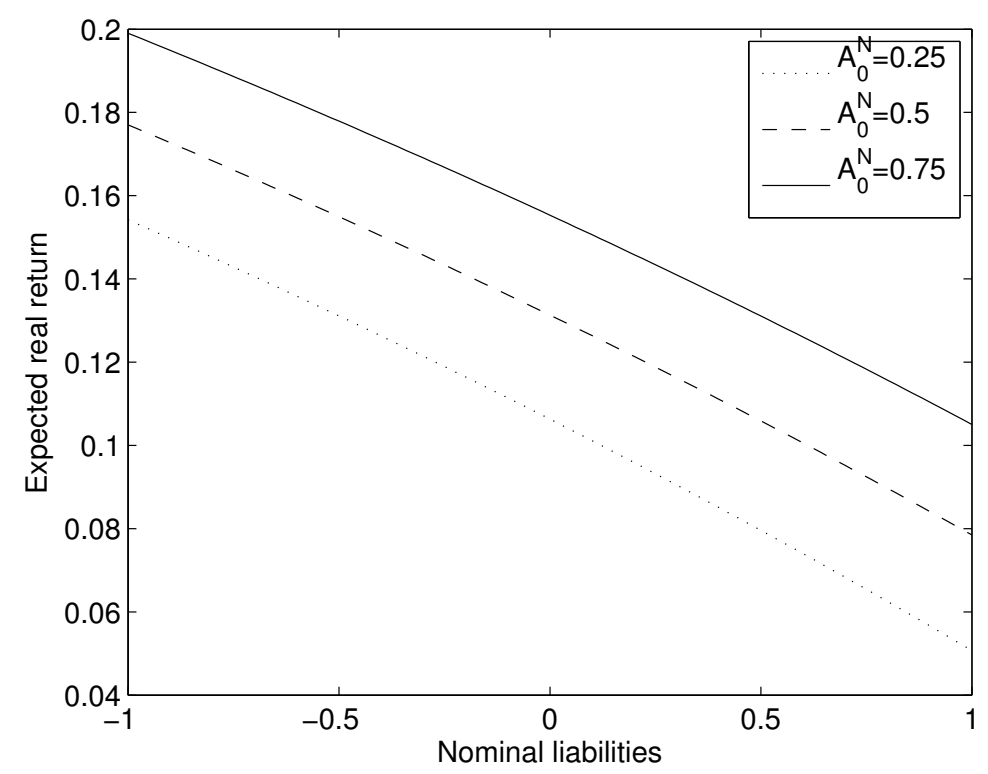

(a) Expectation of real excess return

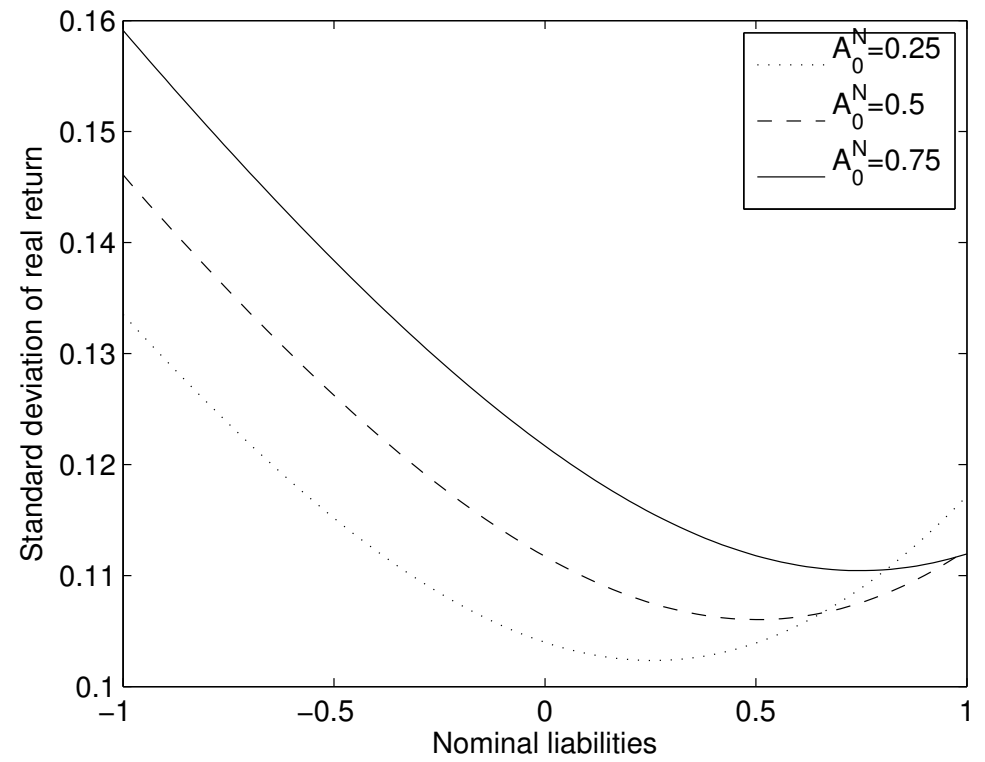

(b) Standard deviation of real excess return

Fig. 2. The figure shows the results from the simulation of the real excess return to firm equity, in Figure 2(a), and its standard deviation, in Figure 2(b). The vectors for nominal assets and liabilities, $A_{0}^{N}, L_{0}^{N}$, are $101 \times 1$ each. The vectors for the normal random variables are $1,000 \times 1$ each. Nominal assets are defined as $A_{0}^{N} \in[0,1]$. We impose that $A_{0}^{N} \geq 0$ for going concern. The values for nominal liabilities $L_{0}^{N}$ are not restricted. Nominal liabilities are $L_{0}^{N} \in[-1,1]$. Initial equity is $E_{0}=1$. Real assets are $A_{0}^{R}=0.1$. Real liabilities are the residual modelled as a linear function of the remaining asset, liability and equity positions, $L_{0}^{R}=E_{0}+A_{0}^{N}-L_{0}^{N}+A_{0}^{R}$. This structure allows us to focus on nominal liabilities, conditional on a given asset structure and initial equity. The random variables are drawn from a normal distribution. The real return on $L_{0}^{R}$ in excess of the risk free rate is $r \sim N(0.05,0.1)$. The return differential between real and nominal items is $\alpha \sim N(0.05,0.05)$. The return differential between assets and liabilities is $\kappa \sim N(0.05,0.04)$. Unexpected inflation is $u \sim N(0,0.05)$. 
Simulation for the real Sharpe ratio

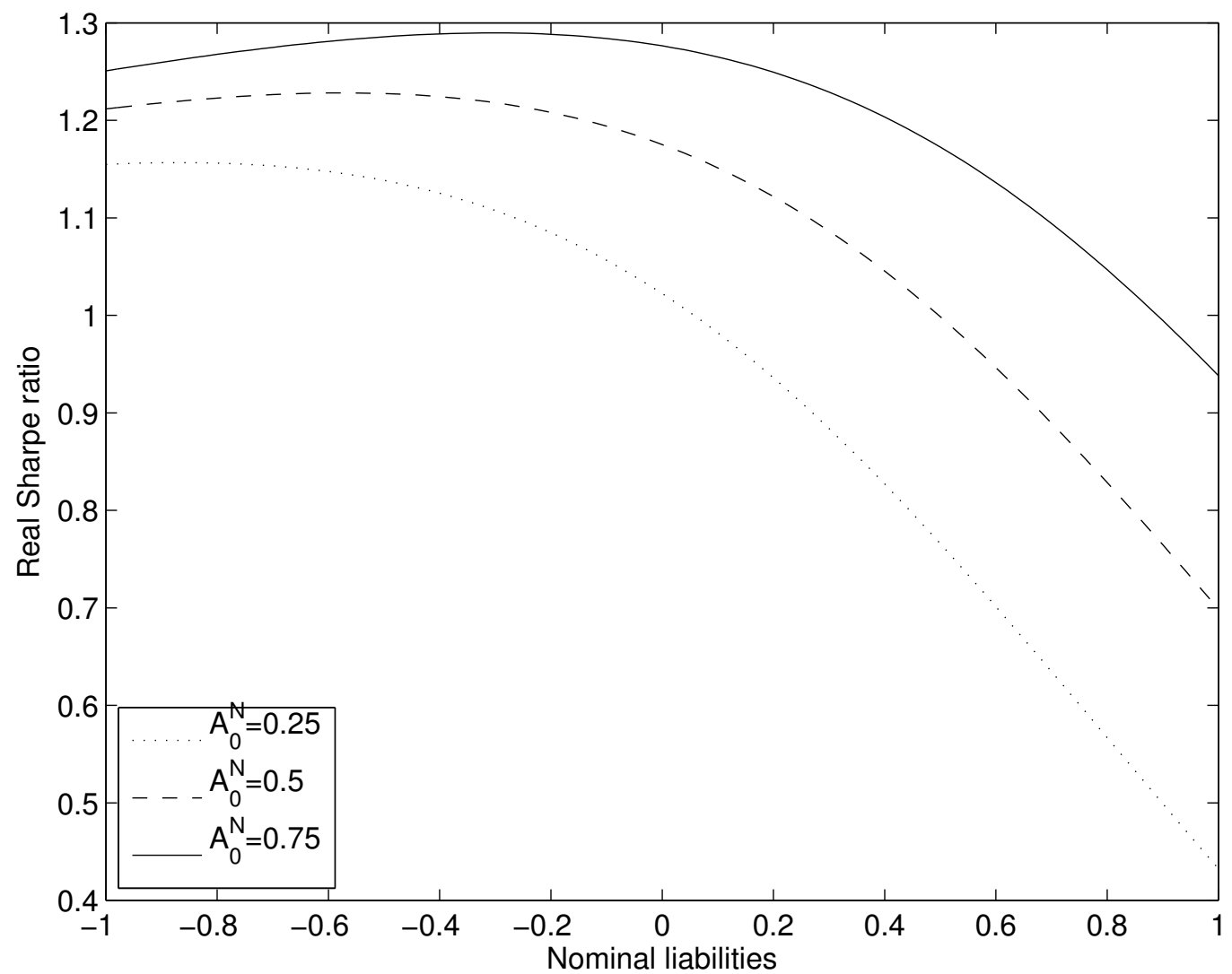

Fig. 3. The figure shows the results from the simulation of the real Sharpe ratio. The vectors for nominal assets and liabilities, $A_{0}^{N}, L_{0}^{N}$, are $101 \times 1$ each. The vectors for the normal random variables are $1,000 \times 1$ each. Nominal assets are defined as $A_{0}^{N} \in[0,1]$. We impose that $A_{0}^{N} \geq 0$ for going concern. The values for nominal liabilities $L_{0}^{N}$ are not restricted. Nominal liabilities are $L_{0}^{N} \in[-1,1]$. Initial equity is $E_{0}=1$. Real assets are $A_{0}^{R}=0.1$. Real liabilities are the residual modelled as a linear function of the remaining asset, liability and equity positions, $L_{0}^{R}=E_{0}+A_{0}^{N}-L_{0}^{N}+A_{0}^{R}$. This structure allows us to focus on nominal liabilities, conditional on a given asset structure and initial equity. The random variables are drawn from a normal distribution. The real return on $L_{0}^{R}$ in excess of the risk free rate is $r \sim N(0.05,0.1)$. The return differential between real and nominal items is $\alpha \sim N(0.05,0.05)$. The return differential between assets and liabilities is $\kappa \sim N(0.05,0.04)$. Unexpected inflation is $u \sim N(0,0.05)$. 


\section{Comparative statics}
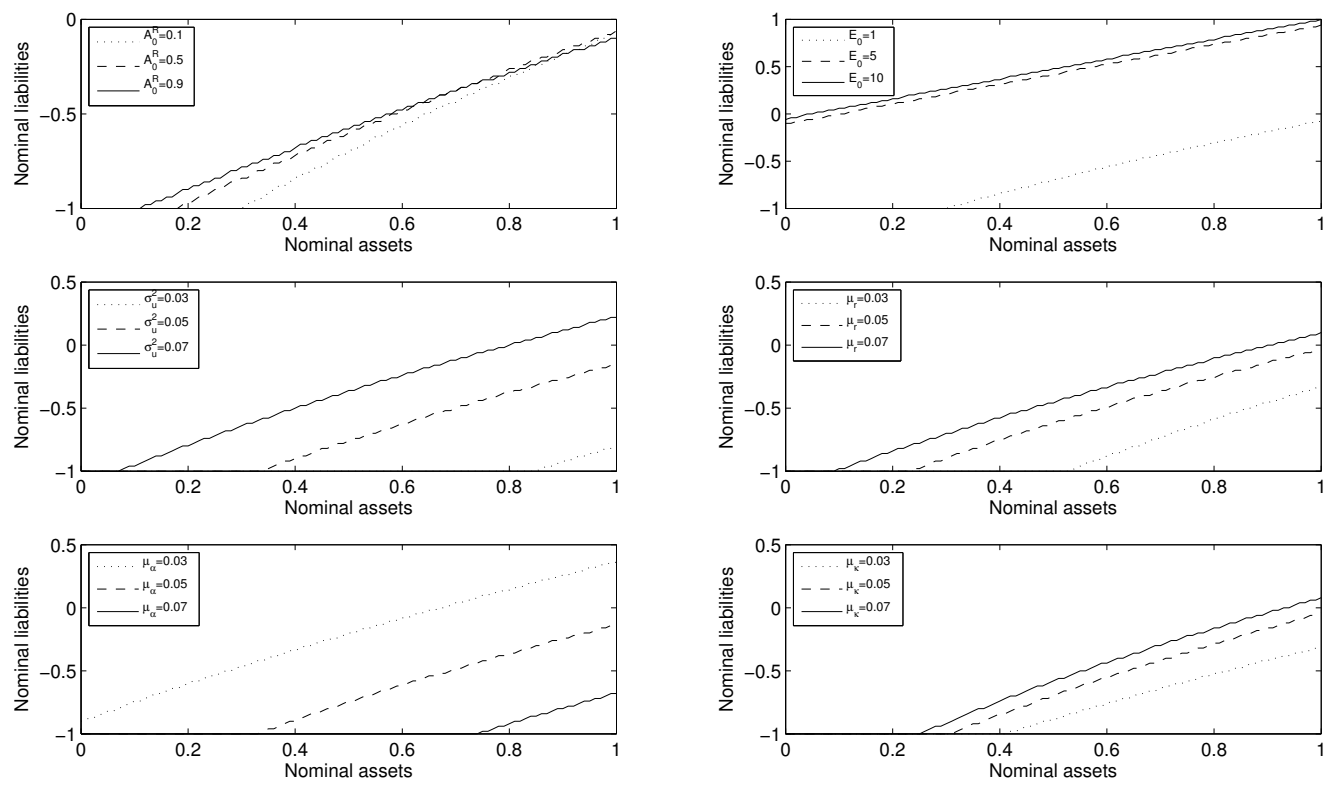

Fig. 4. The figure shows the comparative statics of the model. The vectors for nominal assets and liabilities, $A_{0}^{N}, L_{0}^{N}$, are $101 \times 1$ each. Nominal assets are defined as $A_{0}^{N} \in[0,1]$. We impose that $A_{0}^{N} \geq 0$ for going concern. The values for nominal liabilities $L_{0}^{N}$ are not restricted and are $L_{0}^{N} \in[-1,1]$. Initial equity is $E_{0}=1$. Real assets are $A_{0}^{R}=0.1$. Real liabilities are the residual modelled as a linear function of the remaining asset, liability and equity positions, $L_{0}^{R}=E_{0}+A_{0}^{N}-L_{0}^{N}+A_{0}^{R}$. This structure allows us to focus on nominal liabilities, conditional on a given asset structure and initial equity. The random variables are vectors of $1,000 \times 1$ and drawn from a normal distribution. The real return on $L_{0}^{R}$ in excess of the risk free rate is $r \sim N(0.05,0.1)$. The return differential between real and nominal items is $\alpha \sim N(0.05,0.05)$. The return differential between assets and liabilities is $\kappa \sim N(0.05,0.04)$. Unexpected inflation is $u \sim N(0,0.05)$. The scenarios modify elements of the basic structure one by one as follows: Scenario 1 varies $A_{0}^{R}=[0.1,0.5,0.9]$. Scenario 2 varies $E_{0}=[1,5,10]$. Scenario 3 varies $u \sim N\left(0, \sigma_{u}^{2}\right), \sigma_{u}^{2}=[0.03,0.05,0.07]$. Scenario 4 varies $r \sim N\left(\mu_{r}, 0.1\right), \mu_{r}=[0.03,0.05,0.07]$. Scenario 5 varies $\alpha \sim N\left(\mu_{\alpha}, 0.05\right), \mu_{\alpha}=[0.03,0.05,0.07]$. Scenario 6 varies $\kappa \sim N\left(\mu_{\kappa}, 0.05\right), \mu_{\kappa}=[0.03,0.05,0.07]$. 
Line fit plot of log of nominal assets on unexpected rate of inflation (annual average of monthly figures, based on CPI)

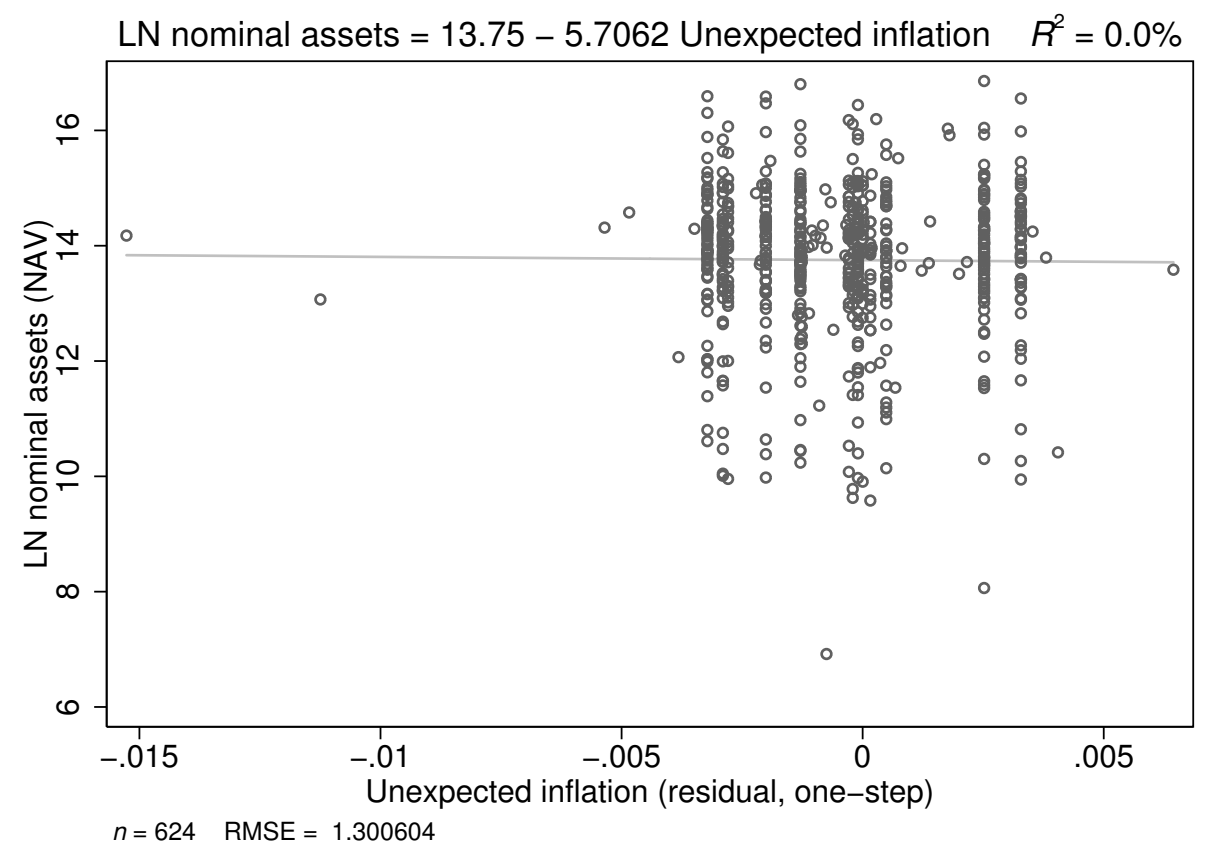

Fig. 5. The figure shows a line fit plot from a regression of my chosen proxy for nominal assets, the natural logarithm of the firm's NAV as reported by $S N L$ (discounted at an average rate of $7.5 \%$ ) on unexpected inflation. I measure unexpected inflation as the residual from filtering monthly logged CPI figures using an $\operatorname{ARIMA}(0,1,1)$ specification (Fama and Gibbons, 1984; Vassalou, 2000). 
Line fit plot of first differences in log of nominal assets on first differences in unexpected rate of inflation (annual average of monthly figures, based on CPI)

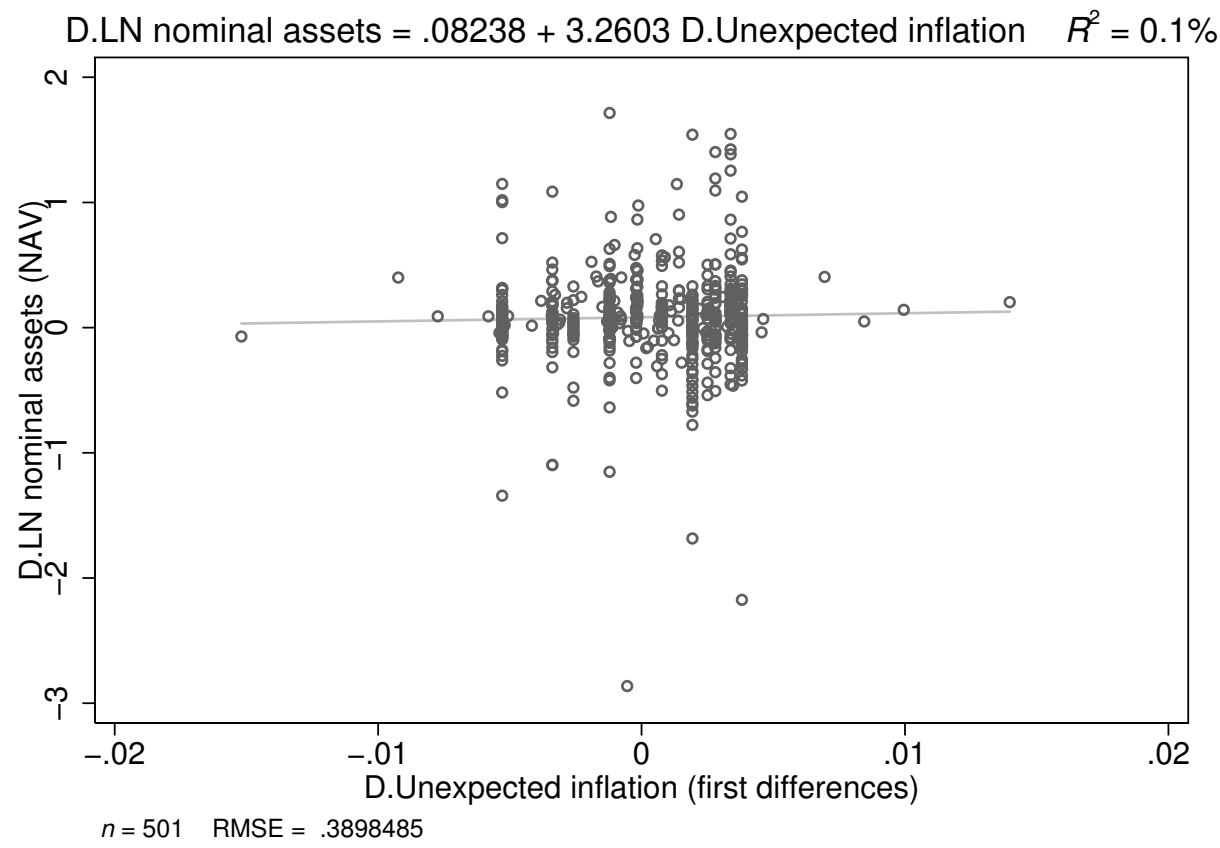

Fig. 6. The figure shows a line fit plot from a regression in first differences of my chosen proxy for nominal assets, the natural logarithm of the firm's NAV as reported by $S N L$ (discounted at an average rate of $7.5 \%$ ) on unexpected inflation. I measure unexpected inflation as the residual from filtering monthly logged CPI figures using an ARIMA(0,1,1) specification (Fama and Gibbons, 1984; Vassalou, 2000). 
Histogram and descriptive statistics of unexpected inflation sensitivities of listed US equity REITs over the full study period 1989-2011

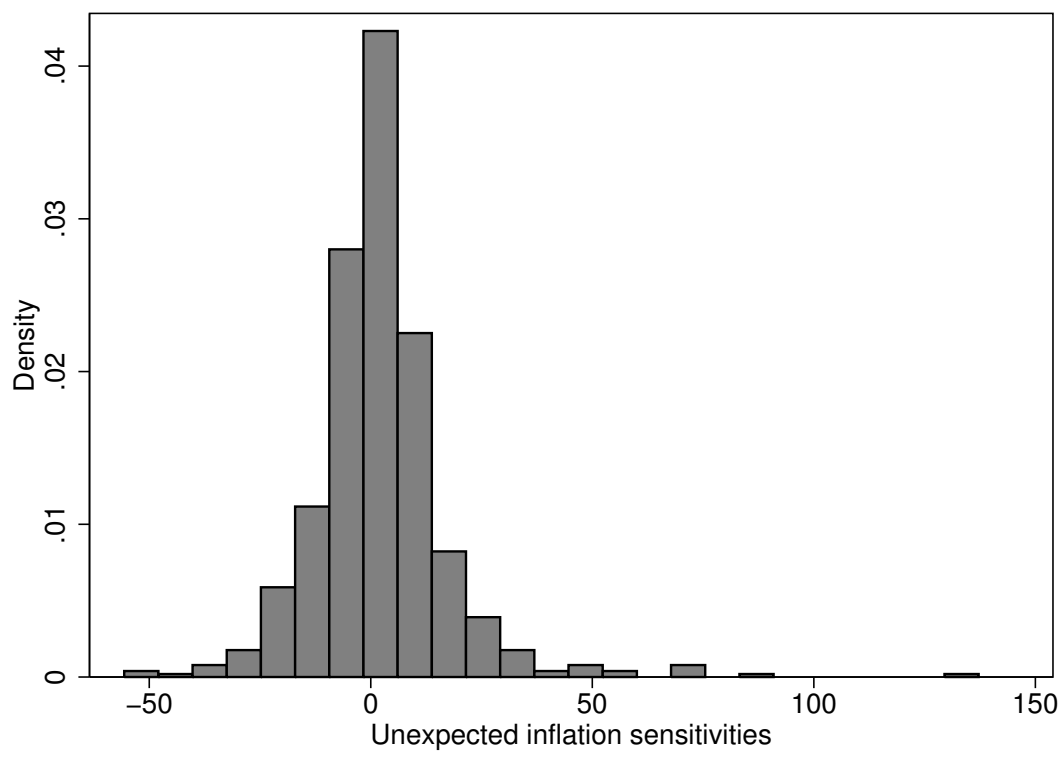

\begin{tabular}{|c|c|c|c|c|}
\hline & Percentiles & Smallest & Statistics & \\
\hline $1 \%$ & -33.513 & -55.653 & Mean & 2.008 \\
\hline $5 \%$ & -19.396 & -50.552 & Standard deviation & 15.313 \\
\hline $10 \%$ & -13.201 & -41.234 & Standard error & 0.595 \\
\hline \multirow[t]{2}{*}{$25 \%$} & -4.754 & -39.822 & $95 \%$ conf. interval & \\
\hline & & & Lower & 0.840 \\
\hline \multirow[t]{2}{*}{$50 \%$} & 0.642 & & Upper & 3.177 \\
\hline & & Largest & t-stat & 3.375 \\
\hline $75 \%$ & 7.873 & 72.019 & $\mathrm{~N}$ & 662 \\
\hline $90 \%$ & 15.997 & 74.747 & Variance & 234.477 \\
\hline $95 \%$ & 22.975 & 86.595 & Skewness & 1.903 \\
\hline $99 \%$ & 56.177 & 137.200 & Kurtosis & 16.220 \\
\hline
\end{tabular}

Fig. 7. The figure shoes a histogram alongside a set of descriptive statistics for the unexpected inflation sensitivities of the listed US equity REITs in our sample over the full study period. These estimates are obtained using annual regressions of the nominal monthly firm excess returns (NRET) on monthly unexpected inflation (UINFL) and a set of controls to obtain the annual coefficients measuring the sensitivity of nominal firm returns to unexpected inflation. We measure unexpected inflation as the residual from filtering monthly logged CPI figures using an $\operatorname{ARIMA}(0,1,1)$ specification (Fama and Gibbons, 1984; Vassalou, 2000), and expected inflation as the predicted values from this exercise. In this regression, we control for the excess return on the market $(M K T)$, size $(S M L)$ and value $(H M L)$ factors, expected inflation $(E X P I N)$ and variation in the interest rate proxied by changes in the federal funds rate $(C F F R)$. We collect the coefficients on the unexpected inflation variable to compile a firm-year panel of unexpected inflation sensitivities. 
Regression results of NAV on unexpected inflation for listed US equity REITs over the full study period 1989-2011

\begin{tabular}{lcccc}
\hline & $(1)$ & $(2)$ & $(3)$ & $(4)$ \\
VARIABLES & LNNA & LNNA & D.LNNA & D.LNNA \\
\hline Unexpected inflation & 28.547 & & & \\
& $(23.73)$ & & & \\
L.Unexpected inflation & & 11.058 & & \\
& & $(31.26)$ & & \\
D.Unexpected inflation & & & 18.228 & \\
& & & $(10.78)$ & \\
L.D.Unexpected inflation & & & & -18.533 \\
& & & & $(18.89)$ \\
Constant & $12.269^{* * *}$ & $12.805^{* * *}$ & $0.544^{*}$ & $0.377^{* *}$ \\
& $(0.23)$ & $(0.05)$ & $(0.25)$ & $(0.12)$ \\
& & & & \\
Observations & 622 & 501 & 501 & 409 \\
R-squared & 0.321 & 0.249 & 0.122 & 0.095 \\
Number of firm clusters & 87 & 81 & 81 & 76 \\
Year dummies & Yes & Yes & Yes & Yes \\
\hline \hline
\end{tabular}

Table 1

The table shows the results from a set of fixed-effects panel regressions of my chosen proxy for nominal assets, the natural logarithm of the firm's NAV as reported by $S N L$ (discounted at an average rate of $7.5 \%$ ) on unexpected inflation (Column (1)) and the lag of unexpected inflation (Column (2)). Columns (3) and (4) replicate these regressions in first differences. I measure unexpected inflation as the residual from filtering monthly logged CPI figures using an ARIMA(0,1,1) specification (Fama and Gibbons, 1984; Vassalou, 2000). Robust standard errors (clustered by firm) are shown in parentheses. Significance is indicated as follows; $* * *$ $\mathrm{p}<0.001,{ }^{*} * \mathrm{p}<0.01,{ }^{*} \mathrm{p}<0.05$. 
Control variables and proxies

\begin{tabular}{|c|c|c|}
\hline Variable & Measurement & References \\
\hline MAT: Debt maturity & $\begin{array}{l}\text { Ratio of long-term debt matur- } \\
\text { ing in more than } 3 \text { years to total } \\
\text { debt }\end{array}$ & Leland and Toft (1996) \\
\hline LNSIZE: Firm size & $\begin{array}{l}\text { Log of market value of the firm's } \\
\text { assets }\end{array}$ & Myers and Majluf (1984) \\
\hline PROFIT: Profitability & $\begin{array}{l}\text { Ratio of EBITDA to book value } \\
\text { of assets }\end{array}$ & $\begin{array}{l}\text { Donaldson (1961); Myers and } \\
\text { Majluf (1984) }\end{array}$ \\
\hline MB: Market-to-book ratio & $\begin{array}{l}\text { Book value of assets minus book } \\
\text { value of common equity plus } \\
\text { market value of common equity } \\
\text { relative to book value of assets }\end{array}$ & Myers (1977) \\
\hline ABEARN: Abnormal earnings & $\begin{array}{l}\text { Change in earnings per share rel- } \\
\text { ative to share price }\end{array}$ & Ross (1977) \\
\hline VOL: Earnings volatility & $\begin{array}{l}\text { Standard deviation of } 1 \text { st diff. in } \\
\text { EBITDA over } 4 \text { years, scaled by } \\
\text { average assets over these years }\end{array}$ & Bradley, Jarrell, and Kim (1984) \\
\hline DNOL: Alternative tax shields & $\begin{array}{l}\text { Dummy for operating loss car- } \\
\text { ried forward, } 1 \text { in presence of al- } \\
\text { ternative tax shield }\end{array}$ & DeAngelo and Masulis (1980) \\
\hline IV for debt maturity & Measurement & Reference \\
\hline AMAT: Asset maturity & $\begin{array}{l}\text { Log of gross depreciable assets to } \\
\text { depreciation expense }\end{array}$ & Myers (1977) \\
\hline DRATED: Debt rating & $\begin{array}{l}\text { Dummy, } 1 \text { in presence of debt } \\
\text { rating }\end{array}$ & $\begin{array}{l}\text { Diamond (1991); Sharpe (1991); } \\
\text { Titman (1992) }\end{array}$ \\
\hline TERM: Term structure & $\begin{array}{l}\text { Yield on } 10-y r \text {. relative to } 6- \\
\text { month government bond }\end{array}$ & Brick and Ravid (1985) \\
\hline IV for nominal assets & Measurement & Reference \\
\hline $\begin{array}{l}\text { LNRPP: Log of rental revenue } \\
\text { per property }\end{array}$ & $\begin{array}{l}\text { Ratio of rental revenue to aver- } \\
\text { age properties }\end{array}$ & Suggested here \\
\hline
\end{tabular}

Table 2

The table shows the main capital structure control variables employed in our regression, alongside their proxies and measurement as well as the reference to the original theory. Where possible, our proxy choices follow the suggestions by the original authors. All firm-level and balance sheet data is obtained from $S N L$ and Compustat. Bond yields have been obtained from the Federal Reserve Bank of St. Louis's Economic Database. 
Descriptive statistics for the sample firms over the full study period 1989-2011

\begin{tabular}{lrrrrrr}
\hline VARIABLES & Mean & Median & Min & Max & S.D. & N \\
\hline Nominal debt to equity ratio & 1.908 & 1.369 & -161.407 & 67.389 & 8.762 & 533 \\
Nominal assets to equity ratio & 2.410 & 2.147 & -97.228 & 56.342 & 6.312 & 533 \\
Firm size & 1277.819 & 668.664 & 0.440 & 16801.184 & 1954.373 & 533 \\
Debt maturity & 0.486 & 0.496 & 0.000 & 1.000 & 0.201 & 533 \\
Asset maturity & 33.097 & 31.430 & 14.306 & 124.528 & 10.142 & 533 \\
Profitability & 0.080 & 0.084 & -0.160 & 0.212 & 0.034 & 533 \\
Market-to-book ratio & 1.236 & 1.190 & 0.576 & 2.457 & 0.287 & 533 \\
Abnormal earnings & -0.021 & -0.002 & -3.065 & 2.818 & 0.283 & 533 \\
Volatility & 0.024 & 0.014 & 0.001 & 0.201 & 0.029 & 533 \\
Proportion of firm years with & & & & & & \\
$\quad$ Loss carried forward & 0.090 & 0.000 & 0.000 & 1.000 & 0.287 & 533 \\
$\quad$ Debt rated dummy & 0.475 & 0.000 & 0.000 & 1.000 & 0.500 & 533 \\
Term structure & 1.852 & 2.160 & -0.350 & 3.610 & 1.345 & 533 \\
\hline \hline
\end{tabular}

Table 3

The table reports descriptive statistics the REITs in our final sample between 1989 and 2011 from Compustat and $S N L$ database. Variables are defined as: Nominal debt to equity is the ratio of fixed-rate debt to book value of equity. Nominal assets to equity is the ratio of the firm's NAV to book value of equity. Log of Firm Size is measured by the natural logarithm of the market value of the firm's assets (in millions of August 1982 US\$, deflated by PPI). Debt Maturity is measured by the proportion of long-term debt relative to total debt. Log of Asset Maturity is measured by the natural logarithm of the ratio of depreciable assets to depreciation. Profitability is measured as the ratio of EBITDA to book value of assets. Market-to-book ratio is measured by the market value of assets divided by the book value of assets. Abnormal Earnings is the difference between earnings per share in year $t+1$ minus earnings per share in year $t$, divided by the year $t$ share price. Earnings volatility is measured by the standard deviation of first differences in EBITDA over the four years preceding the sample year, scaled by average assets for that period. Term Structure is the difference between the month-end yields on a 10-year government bond and a 6-month government bond, matched to the month of a firm's fiscal year end. Bond yields are from the Federal Reserve Bank of St. Louis's economic database. Each of the dummy variables (operating loss carried forward and debt rating) equals 1 if the firm has its respective items, 0 otherwise. 


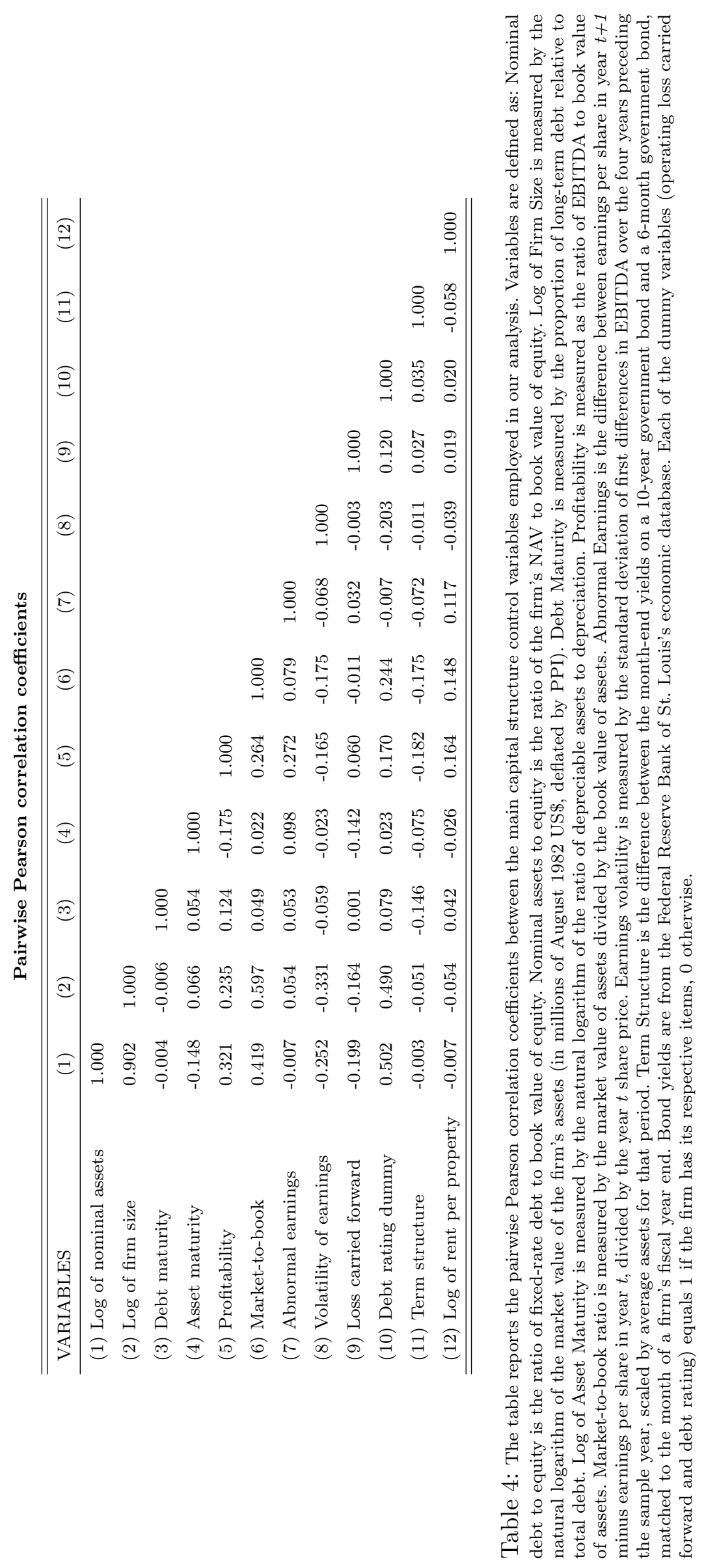


Regression results for Hypothesis 1, 1989-2011

\begin{tabular}{|c|c|c|c|c|}
\hline & $(1)$ & $(2)$ & (3) & $(4)$ \\
\hline VARIABLES & $S R^{R}$ & $S R^{R}$ & $S R^{R}$ & D. $S R^{R}$ \\
\hline Deviation $($ proportion $=0.255)$ & $\begin{array}{c}-0.022^{* * *} \\
(0.00)\end{array}$ & & & \\
\hline Deviation $($ proportion $=0.565)$ & & $\begin{array}{c}-0.034^{* * *} \\
(0.01)\end{array}$ & & \\
\hline Deviation $($ proportion $=1$ ) & & & $\begin{array}{c}-0.015^{* * *} \\
(0.00)\end{array}$ & \\
\hline D.Deviation $($ proportion $=1$ ) & & & & $\begin{array}{c}-0.063^{* * *} \\
(0.01)\end{array}$ \\
\hline Debt maturity & $\begin{array}{l}0.159 \\
(0.15)\end{array}$ & $\begin{array}{l}0.141 \\
(0.15)\end{array}$ & $\begin{array}{l}0.127 \\
(0.15)\end{array}$ & $\begin{array}{l}0.829 \\
(0.74)\end{array}$ \\
\hline Log of firm size & $\begin{array}{l}-0.042 \\
(0.07)\end{array}$ & $\begin{array}{l}-0.044 \\
(0.07)\end{array}$ & $\begin{array}{l}-0.045 \\
(0.07)\end{array}$ & $\begin{array}{l}0.243 \\
(0.28)\end{array}$ \\
\hline Profitability & $\begin{array}{l}0.019 \\
(0.82)\end{array}$ & $\begin{array}{l}-0.001 \\
(0.83)\end{array}$ & $\begin{array}{l}0.126 \\
(0.82)\end{array}$ & $\begin{array}{l}-5.703 \\
(6.39)\end{array}$ \\
\hline Market to book & $\begin{array}{l}0.245 \\
(0.22)\end{array}$ & $\begin{array}{l}0.222 \\
(0.23)\end{array}$ & $\begin{array}{l}0.236 \\
(0.23)\end{array}$ & $\begin{array}{r}-1.279 \\
(1.18)\end{array}$ \\
\hline Abnormal earnings & $\begin{array}{l}-0.011 \\
(0.03)\end{array}$ & $\begin{array}{l}-0.012 \\
(0.03)\end{array}$ & $\begin{array}{l}-0.010 \\
(0.03)\end{array}$ & $\begin{array}{l}-0.001 \\
(0.11)\end{array}$ \\
\hline Volatility of earnings & $\begin{array}{l}1.189 \\
(0.85)\end{array}$ & $\begin{array}{l}1.147 \\
(0.84)\end{array}$ & $\begin{array}{l}1.045 \\
(0.83)\end{array}$ & $\begin{array}{l}1.616 \\
(2.77)\end{array}$ \\
\hline Loss carried forward & $\begin{array}{l}0.024 \\
(0.07)\end{array}$ & $\begin{array}{l}0.033 \\
(0.07)\end{array}$ & $\begin{array}{l}0.033 \\
(0.07)\end{array}$ & $\begin{array}{l}-0.273 \\
(0.37)\end{array}$ \\
\hline Constant & $\begin{array}{l}0.394 \\
(1.22)\end{array}$ & $\begin{array}{l}0.456 \\
(1.24)\end{array}$ & $\begin{array}{l}0.427 \\
(1.25)\end{array}$ & $\begin{array}{l}-3.461 \\
(3.87)\end{array}$ \\
\hline Observations & 451 & 451 & 451 & 439 \\
\hline R-squared & 0.307 & 0.301 & 0.298 & 0.077 \\
\hline Firm clusters & 78 & 78 & 78 & 76 \\
\hline Property type dummies & Yes & Yes & Yes & Yes \\
\hline Year dummies & Yes & Yes & Yes & Yes \\
\hline
\end{tabular}

Table 5

The table presents the results from a set of fixed effects panel regression models for our final sample of REITs over the full period 1989-2011. We estimate the firm's annual real Sharpe ratio (Columns 1 to 3 ) and the change in the annual real Sharpe ratio (column 2) as a function of the deviation $(D E V)$ from its optimal nominal liability holdings (column 1) and the change in this deviation (Column 4). We obtain the annual real Sharpe ratio of a firm by computing its average annual real excess return over the risk-free rate and dividing by the volatility of this return. We measure $D E V$ by computing the annual squared differences between nominal assets and liabilities (both deflated by the Producer Price Index constant in August 1982, in millions of US\$). In Column (1), $D E V$ is calculated using the constant of proportionality obtained from Table 4, Column (1). In Column (2), $D E V$ is calculated using the constant of proportionality obtained from Table 4, Column (4). In Columns (3) and (4), $D E V$ is calculated using a constant of proportionality of unity. We control for the commonly employed capital structure determinants as well as property type and year effects, using dummy variables. Robust standard errors (clustered by firm) in parentheses, significance is indicated as follows: *** $\mathrm{p}<0.01,{ }^{* *} \mathrm{p}<0.05,{ }^{*} \mathrm{p}<0.1$. 
Regression results for Hypothesis 2, 1989-2011

\begin{tabular}{|c|c|c|}
\hline & (1) & $(2)$ \\
\hline VARIABLES & Inflation sensitivity & D.Inflation sensitivity \\
\hline \multirow[t]{2}{*}{ Deviation $($ proportion $=1)$} & $-0.468^{*}$ & \\
\hline & $(0.26)$ & \\
\hline \multirow[t]{2}{*}{ D.Deviation (proportion = 1) } & & -0.484 \\
\hline & & $(0.33)$ \\
\hline \multirow[t]{2}{*}{ Debt maturity } & $-21.963^{* * *}$ & -11.655 \\
\hline & $(6.11)$ & $(8.18)$ \\
\hline \multirow[t]{2}{*}{ Log of firm size } & 0.610 & -3.681 \\
\hline & $(1.88)$ & $(3.19)$ \\
\hline \multirow[t]{2}{*}{ Profitability } & 24.811 & 129.220 \\
\hline & $(26.33)$ & $(85.43)$ \\
\hline \multirow[t]{2}{*}{ Market to book } & $-13.935^{* * *}$ & -1.090 \\
\hline & $(3.75)$ & $(8.60)$ \\
\hline \multirow[t]{2}{*}{ Abnormal earnings } & 1.826 & 3.956 \\
\hline & $(2.67)$ & $(3.53)$ \\
\hline \multirow[t]{2}{*}{ Volatility of earnings } & 55.758 & -58.427 \\
\hline & $(38.50)$ & $(56.12)$ \\
\hline \multirow[t]{2}{*}{ Loss carried forward } & 3.240 & 1.477 \\
\hline & $(3.69)$ & $(6.67)$ \\
\hline \multirow[t]{2}{*}{ Constant } & 15.521 & 49.710 \\
\hline & $(35.13)$ & $(57.22)$ \\
\hline Observations & 440 & 427 \\
\hline R-squared & 0.075 & 0.270 \\
\hline Firm clusters & 75 & 73 \\
\hline Property type dummies & Yes & Yes \\
\hline Year dummies & Yes & Yes \\
\hline
\end{tabular}

Table 6

The table presents the results from a set of fixed effects panel regression models for our final sample of REITs over the full period 1989-2011. We estimate the firms' sensitivity to unexpected inflation as a function of the deviation (assuming a constant of proportionality of unity) from their optimal nominal liabilities (column 1) and present the results from an identical regression considering annual changes in the unexpected inflation beta as a function of changes in this deviation (column 2), controlling for the usual set of capital structure determinants, including maturity, as well as property type and year dummies. We measure the firm's sensitivity to unexpected inflation using annual regressions of the nominal monthly firm excess returns $(N R E T)$ on monthly unexpected inflation (UINFLS). We measure unexpected inflation as the residual from filtering monthly logged CPI figures using an $\operatorname{ARIMA}(0,1,1)$ specification (Fama and Gibbons, 1984; Vassalou, 2000), and expected inflation as the predicted values from this exercise. ${ }^{11}$ In this regression, we control for the excess return on the market $(M K T)$, size $(S M L)$ and value $(H M L)$ factors, expected inflation $(E X P I N)$ and variation in the interest rate proxied by changes in the federal funds rate $(C F F R)$. We collect the coefficients on $U I N F L$, resulting in a firm-year panel of unexpected inflation sensitivities $U I N F L S$. We remedy the bias in the standard errors from heteroskedasticity potentially introduced by the estimated dependent variable using robust standard errors clustered by firm (Lewis and Linzer, 2005). Robust standard errors (clustered by firm) in parentheses, significance is indicated as follows: $* * * \mathrm{p}<0.01$, ** $\mathrm{p}<0.05, * \mathrm{p}<0.1$. 